This is the pre-print of the article published in Journal of Organizational Change Management. The final authenticated version is available online at:

Odriozola-Fernández, I., Berbegal-Mirabent, J., Merigó-Lindahl, J.M. (2019), Open innovation in small and medium enterprises: a bibliometric analysis, Journal of Organizational Change Management, Vol. 32 No. 5, pp. 533-557. https://doi.org/10.1108/JOCM-12-2017-0491

\title{
Open Innovation in Small and Medium Enterprises: A bibliometric analysis
}

Purpose - The Open Innovation (OI) paradigm suggests that firms should use inflows and outflows of knowledge in order to accelerate innovation and leverage markets. Literature examining how firms are adopting OI practices is rich; notwithstanding, little research has addressed this topic from the perspective of small and medium enterprises (SMEs). Given the relevance of SMEs in worldwide economies, this paper provides a comprehensive overview of research on OI in SMEs.

Design / Methodology / approach - 112 academic articles were selected from the Web of Science database. Following a bibliometric analysis, the most relevant authors, journals, institutions and countries are presented. Additionally, the main areas these articles cover are summarized.

Findings - Results are consistent in that the most prolific authors are affiliated with the universities leading the ranking of institutions. However, it is remarkable that top authors in this field do not possess a large number of publications on OI in SMEs, but combine this research topic with other related ones. At the country level, European countries are on the top together with South Korea.

Research limitations - Despite following a rigorous method, other relevant documents not included in the selected databases might have been ignored.

Practical implications - This paper outlines the main topics of interest within this area: impact of OI on firm performance and on organizations' structure, OI as a mechanism to hasten new product development, the analysis of the inbound/outbound dimensions of OI, and legal issues related to IPR management when OI is implemented.

Originality / value - Combination of bibliometric indicators with a literature review.

Keywords - Open innovation, SMEs, bibliometrics, literature review

Paper type - Literature review 


\section{Introduction}

Small and medium-sized enterprises (SMEs) play a paramount role in the development of current and future economies (Bruque and Moyano, 2007). Contemporary firms are constantly evolving. This requires not only a flexible and adaptable workforce able to quickly respond to customers' changing demands but also technological expertise and financial resources, which, conversely, tend to be limited (Vrgovic et al., 2012). In this context, Open Innovation (OI) is seen as a solution to these challenges, enabling companies to foresee the threats of the market and strengthen their business models (van de Vrande et al., 2009). As Chesbrough (2003) describes, OI represents an innovation paradigm shift from a closed to an open model.

OI seeks to use all external knowledge (Mina et al., 2014) to innovate within the company or use all internal knowledge to innovate outside the company. In other words, different agents (Wu et al., 2013; Felin and Zenger, 2014), whether internal or external to the company (Padilla-Meléndez et al., 2012), are involved in the innovation process. Universities, innovation centers and even governments stand out as external agents, playing an essential role in creating value based on the exchange of information and knowledge to improve companies' assets.

The term OI was first used to express the usage of "internal and external knowledge to accelerate internal innovation and expand markets for the external use of such innovation" (Chesbrough, 2003, p.43). The origin of this paradigm shift is clearly explained in a recent publication (Chesbrough, 2016). While collaborating on several projects at the Xerox Research Center (Palo Alto), Chesbrough noted that all projects had a closed innovation approach; everything within the company was transformed. When the funding for those 35 projects ended, Xerox encouraged its employees to launch the projects in the market. Most of these projects failed to survive but five of them succeeded, and some even had a better market capitalization than Xerox. With a different business model, many of those projects that failed could have succeeded. Registering a patent and disseminating it among suppliers and customers might turn such assets into highly profitable opportunities (Granstrad and Holgersson, 2014; Henkel et al., 2014).

Since then, many articles from all sectors have been published in the most important journals on the international scene (Chesbrough, 2003; Laursen and Salter, 2006; van de Vrande et al., 2009; Dahlander and Gann, 2010). The interest in this topic has rapidly spread. 
An example of this is the 'World Open Innovation Conference,' held for 4 years, and 2017's edition was held in San Francisco. Other relevant conferences include the 'Open Innovation 2.0: The Platform for Digital Innovation Conference'—aimed at creating infrastructure that drives the ideas generated from citizens-, the 'Global Open Innovation Driven R\&D Forum', or the forthcoming 'Open Innovation Summit' that will take place in Boston in 2018.

Also, the academic community has echoed the relevance of OI, mainly its broad perspective, but also in SMEs in particular. It is, therefore, not surprising that several leading journals in the fields of management and business have fostered conversations among scholars with calls for papers in special issues. In this respect, it is worth mentioning this current special issue in Organizational Change in Open Innovation, on how organization, and SMEs in particular, manage and articulate different OI practices; or the recent call for papers in Technological Forecasting and Social Change-linked to the SOItmc and CSCOM 2016 conference-, which looked for articles discussing the challenges and opportunities of an open society which is increasingly globalized, with new technologies constantly emerging, and communication channels multiplying exponentially. In this regard, OI also plays a key role, allowing better connection between companies and consumers, which in turn, better respond to customers' needs. As a result, there have been substantial changes in the ways companies operate and in their business models (Chesbrough, 2011). New opportunities have also emerged in the market. SME, partnerships, joint ventures, alliances or capital ventures (Huizingh, 2011; Henkel et al., 2014, Laursen and Salter, 2014, Mina et al., 2014)—whether in an economic or scientific way-, are deploying non-existing technology or knowledge. This allows them to access completely new markets, suppliers, customers, distribution channels, new products or innovation processes.

Research on OI is considerable; however, there are few studies examining OI in SMEs despite these representing the largest number of companies in an economy (Gassmann et al., 2010). Indeed, most of the principles of OI are tailored to large companies. Given that SMEs are less formalized, more flexible, and make decisions faster (Lee et al., 2010), SMEs are particularly well-equipped for adapting and incorporating new ideas. In light of the need to promote OI in SMEs, this article employs a bibliometric analysis to examine the development of research on OI in SMEs. Covering a time horizon of 11 years (2007-2017), this paper examines 112 research papers. The Web of Science database is used as the main source. The current state of the art is therefore presented, including the identification of the most cited articles, the key authors, the most relevant journals, the leading institutions as well as the most 
productive countries investigating this specific topic. According to Merigó and Yang (2017), bibliometric analysis is an attractive field for the scientific community as it allows for the identification, classification and analysis of bibliographies, permitting the generation of summaries of the most outstanding results.

The remainder of the paper is organized as follows. The next section briefly outlines what OI is and how SMEs can benefit from adopting such an approach, by summarizing the main findings from the papers reviewed. The following section explains the methods for the bibliometric analysis. Results are then presented. Findings from these analyses can help researchers realize the importance OI has in SMEs and establish future research directions. The paper ends with some concluding remarks. Limitations are also outlined.

\section{Open innovation in SMEs}

SMEs need to constantly embrace innovation in order to achieve a better position in the market. However, the process of implementing innovation can be arduous and therefore, jeopardize the chances of survival, particularly when resources are scarce (Olander et al., 2009). Rigidity in the legislation is another barrier. Governments generate the most bureaucratic difficulties by preventing knowledge from being easily shared (Padilla-Meléndez et al., 2012). However, recent studies reveal that despite SMEs facing many challenges, when it comes to generating new ideas/knowledge, the adoption of OI practices can help in eliminating barriers, maintaining contact with the market in a simpler manner and without compromising too many resources (Lee et al., 2010; Brunswicker and Vanhaverbeke, 2015).

Certainly, SMEs are very different from large business. They typically have limited cash and resources, which create a vicious circle that prevents them from quick growth. R\&D departments, if any, do not usually spend as much as big companies do (Narula, 2004). Similarly, SMEs lack a formal process for developing new products/services. This implies that SMEs cannot afford the cost of having employees fully dedicated to new product development (Woy and Qing, 2007) and have a limited ability to conduct in-depth customer research on their own (Vrgovic et al., 2012).

Given these particularities, SMEs should innovate using a lower-cost method. In this context, building networks with other companies, research facilities, customers and suppliers are an attractive alternative. This partnership concept allows distinct organizations to 
collaborate to achieve mutual goals, exchange experiences and eliminate the waiting time involved in creating everything from scratch (Bullinger et al., 2004). At the same time, this strategy reduces costs and insecurity arising from development and use of new technologies. Networking is thus a way in which OI can materialize and SMEs can take advantage of this.

The articles that constitute the basis of this bibliometric analysis are diverse, covering a wide range of facets of OI in SMEs. Yet, this paper outlines five general major categories. One group of studies examines the relationship between the adoption of OI practices and firm performance. For instance, Presenza et al. (2017) examine the impact of OI practices on the innovation activity of 191 Italian winemakers that use different external knowledge sources. The ability of these SMEs to acquire and integrate external knowledge into their organizational boundaries is also assessed. Focusing on other metrics of firm performance, Lee et al. (2009) investigate how a concrete measure of financial performance - in this case, operating profit - is related to the variables of openness and closeness in innovation strategy. Also, this group includes those works that aim at identifying factors that hinder the adoption of OI in SMEs. In this respect, Bigliardi and Galati (2016), surveying 157 Italian SMEs, identify four main barriers-knowledge, collaboration, organizational, and financial and strategic - which impede an effective adoption of the OI paradigm. Another example can be found in Pervan et al. (2015), who administered a survey to 200 senior managers in the emerging Dubai market in the United Arab Emirates; they found that several environmental determinants-namely, government supported developments and market dynamics-have a direct impact in supporting OI in SMEs.

A second group of studies are those dealing with the opportunities that OI brings to improve organizations' management. Knowledge is difficult to acquire. OI allows SMEs to take advantage of the competitors by implementing a new way to delegate, motivate, and simplify administrative tasks. From the papers reviewed, there are four critical aspects that need to be considered when implementing OI. First, it is necessary to create a network with universities, stakeholders, and governments, and have a trustworthy relationship with all of them (Vigier, 2007; van Hemert et al., 2013; Dodourova and Bevis, 2014; Anderson and Hardwick, 2017). Second, the structure of the SMEs needs to be re-organized, which means to create work-teams to support the inside-out ideas and receive/develop the outside-in ideas (Ritala et al., 2013; Ullrich and Vladova, 2016). Poorly defined objectives, cultural and administrative problems or the absence of clear guidelines on how to lead teams might diminish the benefits that otherwise could be obtained (Bengtsson et al., 2015; Verbano et al., 
2015). Third, OI should consciously integrate external knowledge with firm capabilities and resources. Studies on how SMEs can develop absorptive capacity are examined in Spithoven et al. (2011), Huang et al. (2015b), Ahn et al. (2016), De Zubielqui et al. (2016), and Valentim et al. (2016). Fourth, it is important to put someone in charge of evaluating the procedures: paths, tasks and management of decisions in order to achieve innovation benefits (Ahn et al., 2017; Battistella et al., 2017).

Another set of studies examines how OI networks help in developing new products/services development (NPD). For example, Vorkapić et al. (2017), using a sample of micro and small enterprises in the manufacturing sector in Serbia, found sound evidence that market pull—close collaboration with the customer-was the prevalent strategy for new product development. Other sources for new ideas for NPD can be obtained from innovation contests, as described in Rodriguez Ferradas et al. (2017). Information systems might also play a significant role in empowering NPD in collaborative networks. This is the setting presented in Rehm et al. (2015), where the authors scrutinize which functionalities information systems should possess in order to facilitate innovation flows in the medical device industry. Going a step further, in Hronszky and Kovács (2013), Living Labs are presented as co-creative spaces where collaborations among consumers, users and producers are quickly developed. These spaces bridge the role between market pull and technology push innovation accelerating new product/service development.

Other studies focus on the two intertwined dimensions of OI (Chesbrough and Crowther, 2006): inbound-leveraging others' technologies by accessing their knowledge (e.g., in-licensing, equity investment, acquisition, R\&D contract)—and outboundtransferring firms' technologies to external organizations for commercial exploitation (e.g., out-licensing, sale of an innovation project, new venture spin-out, joint venture) OI. Concerning the first approach, it is worth mentioning the work of Huang et al. (2015a) which examines the potential impact of external complementary resources on inbound OI and whether transformative capacity acts as a mediator in the process, or the research conducted by Parida et al. (2012) where the research gap covered deals with the effects of a set of different inbound OI activities on innovation performance of SMEs. Although less examined, outbound OI has also been explored. One example is the work of Tranekjer et al. (2012), in the Danish context. Some examples of studies comparing both types of OI can be found in Cagno et al. (2015), Popa et al. (2017) and Usman et al. (2017). 
The last group of articles opens the black box of intellectual property rights (IPRs) in relation to OI in SMEs. Using data from 2,873 Spanish firms, Brem et al. (2017) investigate the relationship between OI and the use of different forms of IPR - patents, industrial designs, trademarks, and copyrights. Their results suggest that SMEs do not benefit from OI or from patenting in the same way as larger firms do, and point out that industrial designs are currently the most efficient mechanisms for SMEs. In a similar vein, Maldonado-Guzmán et al. (2016) explore the relationship between knowledge management and creation of intellectual property within the context of SMEs in Aguascalientes-a region of Mexico. SMEs contribute to innovation and economic growth, despite their resource shortages and lack of professional intellectual property (IP) management practices. Evidence on this topic is also reported from the pharmaceutical sector. Specifically, Eppinger and Vladova (2013) discuss different IP strategies and managing practices placing special emphasis on how these are embedded in the firms' organizational structures.

\section{Methodology}

Bibliometric analyses study the bibliographic material quantitatively (Broadus, 1987). It provides a general overview of a research field according to a wide range of indicators. This study aims not only at determining the most relevant literature in the area and different streams, but also at identifying the main authors, the leading journals, and the institutions that are at the forefront of OI in SMEs.

The first step in a bibliometric study consists in the selection of the database(s) from where the material (in this case, articles) will be gathered. This study selects the Web of Science (WoS) database, which has been widely acknowledged to collect reliable, integrated and multidisciplinary research from multiple sources, on the basis of impact evaluations, fulfilling the highest quality standards (Podsakoff et al., 2008; Yu and Shi, 2015).

The selection of meaningful keywords that unequivocally return papers that fall in this topic is the next step. Two main keywords were selected "open innovation" and "small and medium enterprise*". Because small and medium enterprises can be written in a variety of forms, the following terms were also used in the search strategy: "small or medium enterprise*", "SME*", "medium-sized enterprise*", "small-sized enterprise*". Note that the symbol * allows for the inclusion of the plural. The search was conducted in November 2017, 
resulting in 246 documents. With the objective to concentrate on the most illustrative pieces of research, only "journal articles" were selected. As inclusion criterion, articles should be written in English. After filtering, 138 were obtained. Next, each article was reviewedmainly the abstract, but if necessary the full paper-one by one to check if they addressed OI in SMEs. 26 articles were discarded. 8 of them were about OI but not on SMEs. 11 cover SMEs but OI was not the focus of the research. The remaining 7 were neither focusing on SMEs nor OI. Accordingly, the final sample includes 112 articles.

No restrictions were posed in terms of the time period. This was done on purpose to identify all articles that had covered this topic. As Figure 1 shows, the first article found was published in 2007. The number of publications seems to grow at a fairly steady paceexperiencing some fluctuations-until 2016. However, from 2016 to 2017 the number of papers has increased by $80 \%$, moving from 21 research articles to 38 . The red line indicates the average number of citations per year. It is worth remarking on the peak in 2009, which is due to the pioneer research developed by van de Vrande et al. (2009), with 433 citations, examining the OI practices in the Netherlands SMEs. In this work, these authors demonstrate that OI helps SMEs gain access to market information and technologies, which in turn, create value for their customers.

\section{Insert Figure 1 about here}

Bibliometric studies employ a variety of indicators to signal, among others, how relevant the authors, articles, journals, institutions and countries-among others-are in a specific discipline (Van Leeuwen et al., 2003; Merigó et al., 2016). The main challenge is selecting a few but significant metrics able to capture impact, in the form of both productivity and relevance. In this respect, there is common agreement that frequency counts (e.g., number of articles published), citations, as well as ratios (e.g., citations/article) can perform this role well (Merigó et al., 2017).

Another metric that can provide additional insights is the H-index (Hirsch, 2005), also employed in previous bibliometric studies (Merigó and Yang, 2017). This index integrates publications and citations into one single measure by connecting the number of papers $(n)$ that have received ( $n$ ) citations. In this sense, an author with an H-index of 5 means that s/he has authored 5 papers, with all 5 articles cited, at least, 5 times. 
VOS viewer has been widely used to illustrate bibliographic material (Van Eck and Waltman, 2010). This paper also uses this software. Developed by a research group from Leiden University, VOS viewer is freely available and helps to graphically visualize the results (Cancino et al., 2017).

\section{Results}

\section{Most cited articles}

Table 1 lists the 50 most cited articles from the 112 in the list. As previously mentioned, the article leading this ranking is the work authored by van de Vrande et al. (2009), published in the journal Technovation. There are only 4 additional articles that have received more than 100 citations. Next in the list is the study published in Research Policy elaborated by Lee $e t$ al. (2010). Specifically, in this work the authors place the concept of open innovation in the context of Korean SMEs and suggest the input of an intermediary in facilitating innovation. Impact of innovation performance in SMEs is another topic that has received attention among scholars. This is the case for Parida et al. (2012). Fourth and fifth in the ranking are the works elaborated by Spithoven et al. $(2011,2010)$. Both works, by the same author and published in Technovation, explore inbound OI practices.

\section{Insert Table 1 about here}

Other articles that have received a large number of citations - more than 50 - are the ones by Bianchi et al. (2010) and Spithoven et al. (2013). While the former examines the use of technology in enabling OI initiatives among SMEs, the later compares OI practices between large corporations and SMEs. Although not leading the list, the study conducted by Brunswicker and Vanhaverbeke (2015) is also remarkable, receiving circa 12 citations each year since its publication.

\section{Most influential journals}

The journal with the most publications in OI in SMEs is the International Journal of Technology Management with 9 articles, however, the journal that has the greater impactwhen considering the citations these papers have received - is Technovation, with an average of more than 100 of citations per publication. This result is consistent with the ones displayed in Table 1. Indeed, some of the most cited articles are published in this journal. Following 
this, four journals appear, all with four articles. These journals are the International Small Business Journal, Technology Analysis \& Strategic Management, Business Process Management Journal, and Management Decision; however, none of them score high in terms of the ratio TC/TP. On the contrary, there are two journals-Journal of Small Business Management, and Research Policy - that despite not leading this ranking have published articles that have acquired significant prevalence among scholars, receiving a significant number of citations. Note that all these journals - except the Business Process Management Journal-are well-established in the sense that they enjoy a solid reputation within the academic community. This is not the case for the Technology Innovation Management Review, the European Journal of Innovation Management, or the International Journal of Innovation Management, which have surprisingly entered this ranking. These journals are relatively young and they have probably been created to provide specific space for conversations that specifically deal with innovation-note that the term "innovation" is included in the title of the journal. It would be interesting to follow the evolution of these journals in the forthcoming years.

Insert Table 2 about here

Figure 2 displays the co-citation analysis. That is, the frequency with which two articles are cited together by the same third document. As it can be observed, four types of journals are represented: coloured in green, those journals that refer to management; in red, journals dealing with technology and innovation journals; in yellow, entrepreneurship journals; and finally, in blue, organizational and leadership journals. Three focal journals are located in the centre of the map. The red big circle stands for Research Policy, and the other two are Technovation and Research and Development Management.

Insert Figure 2 about here

\section{Most productive and influential authors}

The most prolific author is Wim Vanhaverbeke, from Hasselt University (Belgium), with four papers that have conjointly received 526 citations. His works mainly focus on the future of OI in SMEs, patterns of OI, access to external sources of information, as well as OI projects that are based on the science or in the market share. Another distinguished author is Andre Spithoven (also from Belgium), with four articles and an average of 76.5 citations per article-note that all four articles are in the top 9 of most cited articles. One of his most 
salient works is the one where he describes absorption capacity to organize inbound OI. Third and fourth in the ranking - both with four articles - are Byungun Yoon, from Dongguk University in South Korea, and Jozsef Toth from Corvinus University of Budapest (Hungary), with 281 and 11 citations, respectively.

\section{Insert Table 3 about here}

As for the authors with 3 articles-Manlio Del Giudice, Veronica Scuotto and JinHyo Joseph Yun - they all share the common feature of having received a low number of citations. Specifically, Del Giudice and Scuotto have co-authored the same three articles, all of them published in 2017; therefore, the low number of citations is not surprising, as the articles have recently been published. On the other hand, the three articles authored by Yun, date in 2015, 2016 and 2017. Other authors that have a significant impact, despite low production, are Sungjoo Lee from Ajou University in South Korea (2 papers, 281 citations), and the Belgians Bart Clarysse and Mirjam Knockaert, from University of Ghent (co-authors, both with 214 citations from 2 articles).

The analysis in VOS viewer confirms the results reported above. As shown in Figure 3, Van de Vrande is the author whose publications are the most cited ones, followed by Lee and Spithoven. The closer and the more lines between the authors, the more influential and more relationships exist among them.

Insert Figure 3 about here

\section{Most relevant institutions}

Institutions have been ranked based on the number of publications, and in case of a tie, taking into account the impact of these works-calculated by dividing the total number of publications by the total number of citations these papers have received. Table 4 displays the results. Universities and research centers from South Korea seem to play a relevant role (10 out of 50), with Dongguk University, Sungkyunkwan University and Seoul National University among the top 6 . This result is congruent with those in Table 3 , where we saw that 8 of the most relevant authors are indeed from this country. Also Belgian institutions are interested in OI practices in SMEs. Specifically, Hasselt University, University of Ghent, Vlerick Business School, the Belgian Science Policy Office, KU Leuven, and HogeschoolUniversiteit Brussel. Politecnico di Milano (Itlay) is third in the ranking, with four publications and 85 citations. 
Insert Table 4 about here

In terms of the number of authors from these institutions, Politecnico di Milano is the one with the highest number of researchers (8) investigating this topic, followed by Sungkyunkwan University and Sogang University (South Korea), University of Cambridge (UK), Università di Padova (Italy), University of Twente (Netherlands), and Lappeenranta University of Technology (Finland), all with 5 researchers.

Calculating the ratio impact/author, there are three institutions-École Polytechnique Fédérale de Lausanne (Switzerland), Eindhoven University of Technology (Netherlands), and the Electronics and Telecommunications Research Institute (South Korea) - that clearly outperform. This is because there is only one author from each of these institutions, and the paper authored by them has achieved a large number of citations. In fact, the first two institutions are the home of V. van de Vrande and M. de Rochemont, two of the authors of the most cited articles. Similarly, G. Park is the author of the second most cited article.

\section{Most productive countries}

The 112 articles selected are authored by researchers located in 35 different countries (see Table 5). UK (19 articles), Italy (16), South Korea (12), and Belgium (11) lead the rank in terms of total number of articles published. These countries are also the ones hosting the highest number of researchers investigating OI in SMEs, if we also include China and Spain -with 19 and 18 researchers, respectively - and the number of institutions where this research is carried. European countries seem to dominate this topic, with the exception of South Korea and China, and the modest role played by the USA (6 papers). In terms of impact - citations divided by the number of publications-, the Netherlands ranks first. It is also worth mentioning the role played by Sweden and North Ireland, when analyzing the ratio impact/institutions, meaning that institutions from these two countries have, on average, a notable proportion of citations per publications. Brazil and Switzerland appear as outliers, with only one publication with a high impact—signaling that the paper has received many citations.

\section{Insert Table 5 about here}

Going a step further in the analysis, Figure 4 shows the bibliographic coupling of the papers in the sample. Bibliographic coupling among countries occurs when two or more countries cite a third document from another country. As shown in the figure, countries can be 
grouped in three main groups, being those colored in green the ones with the have received the largest number of citations.

\section{Insert Figure 4 about here}

\section{Most relevant keywords}

Taking into account the keywords suggested by the authors in their articles, this paper finds that, unsurprisingly, the most common keyword is "open innovation" (used 63 times), followed by SMEs (49 times). Figure 5 graphically illustrates the most common keywords in the form of a cloud: the bigger the size, the more frequent a keyword is. Lagging far behind OI and SMEs, other relevant key terms are "knowledge" (frequency count: 19), technology (15), innovation (11) and absorptive capacity (10). Below the threshold of 10, the other words refer to "R\&D management" (9), "collaboration" and "networks" (8), "IP management" (7), "case study" (5), and "external knowledge" and "new product development" (4). All these words give us an idea of the research topics covered in the papers reviewed.

Insert Figure 5 about here

The most relevant keywords can also be mapped (Figure 6). This way it is possible to observe how they are interconnected among different documents. In addition, Figure 6 also takes into account the relevance of the different keywords by year of publication (from 2007 to 2017).

\section{Insert Figure 6 about here}

Similar to keyword analysis, the software VOS viewer allows for mapping the most relevant terms used in the papers reviewed, not only those terms appearing as keywords, but also considering the terms employed in the titles and abstracts. Figure 7 shows the results. Each circle represents a term for one or more publications. The more occurrences of certain terms in the publications, the closer they are represented. For illustrative purposes, a threshold of at least 12 occurrences has been established. It is also relevant to note that the term "medium-sized enterprises" has been excluded since it was already included as "medium enterprise". 


\section{Discussion and conclusions}

The global economy requires companies to quickly implement innovation and anticipate customers' demands. Compared to large companies, SMEs have the additional challenge of facing these demands with, typically, fewer resources. In this context, OI seems to be a suitable alternative for SMEs to create value, as it allows firms to bring ideas from the outside, permits access to new markets, expands the network, and contributes to improve internal processes. All these activities can be performed at a much lower cost than that of developing the idea internally. Given the relevance of OI in helping SMEs develop, this paper aims at providing a comprehensive overview of the existing literature on this topic, and the identification of the main authors, journals, institutions and countries interested in it.

This paper used a bibliometric analysis to synthesize the main topics discussed in the works that have been published. First, from the literature review, it can be concluded that successful practices of OI in SMEs are highly tied to the cultural, financial, and technological aspects that need to be discussed when implementing an OI strategy. The ultimate goal of OI is to ease the flow of information, resources and expertise from one company to another; however, it is not enough to "open" the firm, but agree on the terms and make sure all parts involved can benefit from this transaction. While in the past most companies relied on closed innovation approaches, current investigations reveal the importance of combining closed and open approaches (Enkel et al., 2009). Too much openness might result in a loss of control and being extremely devoted to external sources can also be harmful in terms of costs (Felin and Zenger, 2014). Likewise, being too closed might imply loss of sight — an inadequate rhythm of innovation - due to the lack of information flows from the market. In such a scenario, the resulting innovation is achieved by means of the technology, tools and knowledge available only within the company. Although a business model based on closed innovation is accepted-when complexity and divergence goals are constant (Almirall and CasadesusMasanell, 2010) - a proper balance between both approaches seems to report better results.

Concerning the bibliometric analysis, several concluding remarks can be drawn. First, results show that publications addressing this double issue (OI in SMEs) started appearing in 2007. Second, there are only four articles that have been cited more than 100 times. The other papers have received less attention. The reason for this might be twofold. On the one hand, the researchers that have authored these articles are also those that have an active role in investigating this topic, meaning that they are works that are becoming seminal articles. On 
the other hand, the timespan between publication and citation needs to be considered, meaning that probably, in the next couple of years, the number of papers surpassing the threshold of 100 citations might increase. At the country level, European countries-and particularly UK, Italy and Belgium — seem to be leading investigations in this topic; however, it is worth noting the interest of South Korean institutions taking part in this conversation. The supremacy of these countries is also found when looking at the most prolific authors. As for the typical outlet for research on OI in SMEs, the analysis reveals that both traditional journals - such as International Journal of Technology Management or Technovation - and journals that have entered more recently on the JCR list-International Small Business Journal, Technology Analysis \& Strategic Management, Business Process Management Journal, Management Decision — are interested in publishing works dealing with this topic.

Although a rigorous methodology was followed, there are some limitations that are worth mentioning. The first limitation relates to the limited sample-112 articles. Further studies might consider expanding the search in other databases in a search for additional relevant contributions, including works in the form of book chapters, conference proceedings among others. Second, this study adopts a quantitative approach — by quantifying the number of papers, journals, authors, etc.- - but has some limitations in translating these results into qualitative ones. Despite the metrics employed having been widely acknowledged to be adequate for bibliometric studies - e.g., citations, impact factor of journals - their ability to reflect quality might be doubtful.

\section{References}

Ahn, J.M., Ju, Y., Moon, T.H., Minshall, T., Probert, D., Sohn, S.Y. and Mortara, L. (2016), "Beyond absorptive capacity in open innovation process: the relationships between openness, capacities and firm performance", Technology Analysis \& Strategic Management, Vol. 28 No. 9, pp. 1009-1028.

Ahn, J.M., Minshall, T. and Mortara, L. (2017), "Understanding the human side of openness: the fit between open innovation modes and CEO characteristics", $R \& D$ Management, DOI: $10.1111 / \mathrm{radm} .12264$.

Almirall, E., \& Casadesus-Masanell, R. (2010), “Open versus closed innovation: A model of discovery and divergence", Academy of Management Review, Vol. 35 No.1, pp. 27-47. 
Anderson, A. R. and Hardwick, J. (2017), "Collaborating for innovation: the socialised management of knowledge", International Entrepreneurship and Management Journal, Vol. 13 No. 4, pp. 1181-1197.Battistella, C., Battistella, C., De Toni, A.F., De Toni, A.F., Pessot, E. and Pessot, E. (2017), "Practising open innovation: a framework of reference”, Business Process Management Journal, Vol. 23 No. 6, pp. 1311-1336.

Bengtsson, L., Lakemond, N., Lazzarotti, V., Manzini, R., Pellegrini, L. and Tell, F. (2015), "Open to a select few? Matching partners and knowledge content for open innovation performance", Creativity and Innovation Management, Vol. 24 No. 1, pp, 72-86.

Bianchi, M., Campodall'Orto, S., Frattini, F. and Vercesi, P. (2010), "Enabling open innovation in small-and medium-sized enterprises: how to find alternative applications for your tecnologies", $R \& D$ Management, Vol. 40 No. 4, pp. 414-431.

Bigliardi, B. and Galati, F. (2016), "Which factors hinder the adoption of open innovation in SMEs?” Technology Analysis \& Strategic Management, Vol. 28 No. 8, pp. 869-885.

Brem, A., Nylund, P. A. and Hitchen, E. (2017), “Open Innovation and Intellectual Property Rights: How do SMEs benefit from patents, industrial designs, trademarks and copyrights?", Management Decision, Vol. 55 No. 6, pp. 1285-1306.

Broadus, R. (1987), "Toward a definition of 'bibliometrics"”, Scientometrics, Vol. 12 No. 5-6, pp. 373-379.

Brunswicker, S. and Vanhaverbeke, W. (2015), "Open innovation in small and medium-sized enterprises (SMEs): External knowledge sourcing strategies and internal organizational facilitators", Journal of Small Business Management, Vol. 53 No. 4, pp. 1241-1263.

Bruque, S. and Moyano, J. (2007), "Organisational determinants of information technology adoption and implementation in SMEs: The case of family and cooperative firms", Technovation, Vol. 27 No. 5, pp. 241-253.

Caetano, M. and Amaral, D.C. (2011), "Roadmapping for technology push and partnership: A contribution for open innovation environments", Technovation, Vol. 31 No. 7, pp. 320335 .

Cagno, E., Ramirez-Portilla, A. and Trianni, A. (2015), "Linking energy efficiency and innovation practices: Empirical evidence from the foundry sector", Energy Policy, Vol. 83, pp. 240-256.

Cancino, C., Merigó, J.M., Coronado, F., Dessouky, Y. and Dessouky, M. (2017), "Forty years of Computers \& Industrial Engineering: A bibliometric analysis", Computers \& Industrial Engineering, Vol. 113, pp. 614-629. 
Chesbrough, H. (2003), "The logic of open innovation: managing intellectual property", California Management Review, 45(3), 33-58.

Chesbrough, H. (2011), "Bringing open innovation to services", MIT Sloan Management Review, Vol. 52 No. 2, pp. 85-90.

Chesbrough, H. (2016), Innovacion abierta. Innovar con éxito en el siglo XXI. Madrid: Openmind de BBVA.

Chesbrough, H. and Crowther, A. K. (2006), "Beyond high tech: Early adopters of open innovation in other industries", $R \& D$ Management, Vol. 36 No. 3, pp. 229-236.

Dahlander, L. and Gann, D. M. (2010), “How open is innovation?”, Research Policy, Vol. 39 No. 6, pp. 699-709.

De Zubielqui, G.C., Jones, J. and Lester, L. (2016), “Knowledge inflows from market-and science-based actors, absorptive capacity, innovation and performance-A study of SMEs”, International Journal of Innovation Management, Vol. 20 No. 6, pp. 1650055.

Dodourova, M. and Bevis, K. (2014), "Networking innovation in the European car industry: Does the Open Innovation model fit?" Transportation Research Part A: Policy and Practice, Vol. 69, pp. 252-271.

Enkel, E., Gassmann, O. and Chesbrough, H. (2009), “Open R\&D and open innovation: Exploring the phenomenon", R\&D Management, Vol. 39 No. 4, pp. 311-316.

Eppinger, E. and Vladova, G. (2013), "Intellectual property management practices at small and medium-sized enterprises", International Journal of Technology Management, Vol. 61 No. 1, pp. 64-81.

Felin, T. and Zenger, T. R. (2014), "Closed or open innovation? Problem solving and the governance choice", Research Policy, Vol. 43 No. 5, pp. 914-925.

Gassmann, O., Enkel, E. and Chesbrough, H. (2010), "The future of open innovation", $R \& D$ Management, 40(3), 213-221.

Granstrand, O. and Holgersson, M. (2014), "The challenge of closing open innovation: The intellectual property disassembly problem", Research-Technology Management, Vol. 57 No. 5, pp. 19-25.

Granstrand, O. and Holgersson, M. (2014), "The challenge of closing open innovation: The intellectual property disassembly problema", Research-Technology Management, Vol. 57 No. 5, pp. 19-25.

Henkel, J., Schöberl, S. and Alexy, O. (2014), “The emergence of openness: How and why firms adopt selective revealing in open innovation", Research Policy, Vol. 43 No. 5, pp. 879-890. 
Hronszky, I. and Kovács, K. (2013), “Interactive value production through Living Labs”, Acta Polytechnica Hungarica, Vol. 10 No. 2, pp. 89-108.

Huang, F., Rice, J. and Martin, N. (2015b), "Does open innovation apply to China? Exploring the contingent role of external knowledge sources and internal absorptive capacity in Chinese large firms and SMEs", Journal of Management \& Organization, Vol. 21 No. 5, pp. 594-613.

Huang, H.C., Lai, M.C. and Huang, W.W. (2015a), "Resource complementarity, transformative capacity and inbound open innovation”, Journal of Business \& Industrial Marketing, Vol. 30 No. 7, pp. 842-854.

Huizingh, E.K. (2011), "Open innovation: State of the art and future perspectives", Technovation, Vol. 31 No. 1, pp. 2-9.

Laursen, K. and Salter, A. (2006), “Open for innovation: the role of openness in explaining innovation performance among UK manufacturing firms", Strategic Management Journal, Vol. 27 No. 2, pp. 131-150.

Laursen, K. and Salter, A. J. (2014), “The paradox of openness: Appropriability, external search and collaboration", Research Policy, Vol. 43 No. 5, pp. 867-878.

Lee, S., Park, G., Yoon, B. and Park, J. (2010), "Open innovation in SMEs-An intermediated network model", Research Policy, Vol. 39 No. 2, pp. 290-300.

Lee, Y. G., Park, S. H. and Song, Y. I. (2009), "Which is better for a firm's financial performance: An externally oriented or inwardly oriented innovation strategy? An empirical study on Korean SMEs", Asian Journal of Technology Innovation, Vol. 17 No. 1, pp. 57-73.

López, S. F., Astray, B. P., Pazos, D. R. and Calvo, N. (2015), "Are firms interested in collaborating with universities? An open-innovation perspective in countries of the South West European Space”, Service Business, Vol. 9 No. 4, pp. 637-662.

Maldonado-Guzmán, G., Lopez-Torres, G.C., Garza-Reyes, J.A. and Martinez-Covarrubias, J.L. (2016), "Knowledge managment as intellectual property: Evidence from Mexican manufacturing SMEs”, Management Research Review, Vol. 39 No. 7, pp. 830-850.

Merigó, J.M., Blanco-Mesa, F., Gil-Lafuente, A.M. and Yager, R.R. (2017), “Thirty years of the International Journal of Intelligent Systems: A bibliometric review", International Journal of Intelligent Systems, Vol. 32 No. 5, pp. 526-554.

Merigó, J.M., Cancino, C.A., Coronado, F. and Urbano, D. (2016), “Academic research in innovation : A country analysis", Scientometrics, Vol. 108, pp. 559-593.

Merigó, J.M. and Yang, J-B. (2017), “A bibliometric analysis of operations research and 
management science", Omega, Vol. 73, pp. 37-48.

Mina, A., Bascavusoglu-Moreau, E. and Hughes, A. (2014), "Open service innovation and the firm's search for external knowledge", Research Policy, Vol. 43 No. 5, pp. 853-866.

Narula, R. (2004), "R\&D collaboration by SMEs: new opportunities and limitations in the face of globalisation", Technovation, Vol. 24 No.2, pp. 153-161.

Olander, H., Hurmelinna-Laukkanen, P. and Mähönen, J. (2009), "What's small size got to do with it? Protection of intellectual assets in SMEs", International Journal of Innovation Management, 13(03), 349-370.

Padilla-Meléndez, A., Del Aguila-Obra, A.R. and Lockett, Nigel. (2012), "Shifting Sands. Regional Perspectives on the Role of Social Capital in Supporting Open Innovation through Knowledge Transfer and Exchange with Small and Medium-sized Enterprizes”, International Small Business Journal, Vol. 31 No. 3, pp. 296-318.

Parida, V., Westerberg, M. and Frishammar, J. (2012), "Inbound open innovation activities in high-tech SMEs: the impact on innovation performance", Journal of Small Business Management, Vol. 50 No. 2, pp. 283-309.

Pervan, S., Al-Ansaari, Y. and Xu, J. (2015), "Environmental determinants of open innovation in Dubai SMEs”, Industrial Marketing Management, Vol. 50, pp. 60-68.

Podsakoff, P.M., MacKenzie, S.B., Podsakoff, N.P. and Bachrach, D.G. (2008), “Scholarly influence in the field of management: A bibliometric analysis of the determinants of university and author impact in the past quarter century", Journal of Management, Vol. 34, pp. 641-720.

Popa, S., Soto-Acosta, P. and Martinez-Conesa, I. (2017), "Antecedents, moderators, and outcomes of innovation climate and open innovation: An empirical study in SMEs", Technological Forecasting and Social Change, Vol. 118, pp. 134-142.

Presenza, A., Abbate, T., Meleddu, M. and Cesaroni, F. (2017), "Small-and medium-scale Italian winemaking companies facing the open innovation challenge", International Small Business Journal, Vol. 35 No. 3, pp. 327-348.

Rehm, S.V., Goel, L. and Junglas, I. (2015), "Role of information systems in empowering innovation networks", MIS Quarterly Executive, Vol. 14 No. 3, pp. 87-103.

Ritala, P., Henttonen, K., Salojärvi, H., Sainio, L.M. and Saarenketo, S. (2013), “Gone fishing for knowledge? The effect of strategic orientations on the scope of open knowledge search", Baltic Journal of Management, Vol. 8 No. 3, pp. 328-348. 
Rodriguez Ferradas, M.I., Alfaro Tanco, J.A. and Sandulli, F. (2017), "Relevant factors of innovation contests for SMEs", Business Process Management Journal, Vol. 23 No 6, pp. 1196-1215.

Schuurman, D., De Marez, L. and Ballon, P. (2016), "The impact of living lab methodology on open innovation contributions and outcomes", Technology Innovation Management Review, Vol. 1 No. 6, pp. 7-16.

Spithoven, A., Clarysse, B. and Knockaert, M. (2011), "Building absorptive capacity to organise inbound open innovation in traditional industries", Technovation, Vol. 31 No. 1, pp. 10-21.

Spithoven, A., Vanhaverbeke, W. and Roijakkers, N. (2013), "Open innovation practices in SMEs and large enterprises”, Small Business Economics, Vol. 41 No. 3, pp. 537-562.

Tranekjer, T.L. and Knudsen, M.P. (2012), “The (unknown) providers to other firms' new product development: what's in it for them?", Journal of Product Innovation Management, Vol. 29 No. 6, pp. 986-999.

Ullrich, A. and Vladova, G. (2016), "Weighing the pros and cons of engaging in Open Innovation", Technology Innovation Management Review, Vol. 6 No. 4, pp. 34-40.

Usman, M., Usman, M., Vanhaverbeke, W. and Vanhaverbeke, W. (2017), "How start-ups successfully organize and manage open innovation with large companies", European Journal of Innovation Management, Vol. 20 No. 1, pp. 171-186.

Valentim, L., Lisboa, J.V. and Franco, M. (2016), "Knowledge management practices and absorptive capacity in small and medium-sized enterprises: Is there really a linkage?", $R \& D$ Management, Vol. 46 No. 4, pp. 711-725.

van de Vrande, V., De Jong, J.P., Vanhaverbeke, W. and De Rochemont, M. (2009), “Open innovation in SMEs: Trends, motives and management challenges", Technovation, Vol. 29 No. 6, pp. 423-437.

Van Eck, N. J. and Waltman, L. (2010), "Software survey: VOSviewer, a computer program for bibliometric mapping", Scientometrics, Vol. 84, pp. 523-538.

van Hemert, P., Nijkamp, P. and Masurel, E. (2013), "From innovation to commercialization through networks and agglomerations: Analysis of sources of innovation, innovation capabilities and performance of Dutch SMEs", Annals of Regional Science, Vol. 50 No. 2, pp. 425-452.

Van Leeuwen, T.N., Visser, M.S., Moed, H.F., Nederhof, T.J. and Van Raan, A.F.J. (2003), "The holy grail of science policy: Exploring and combining bibliometric tools in search of scientific excellence”, Scientometrics, Vol. 57 No. 2, pp. 257-280. 
Verbano, C., Crema, M. and Venturini, K. (2015), "The identification and characterization of open innovation profiles in Italian small and medium-sized enterprises", Journal of Small Business Management, Vol. 53 No. 4, pp. 1052-1075.

Vigier, P. (2007), “Towards a Citizen-driven Innovation System in Europe: A governance approach for a European innovation agenda”, Innovation, Vol. 20 No. 3, pp. 191-202.

Vorkapić, M., Radovanović, F., Ćoćkalo, D. and Đorđević, D. (2017), "NPD in small manufacturing enterprises in Serbia", Technical Gazette, Vol. 24 No. 1, pp. 327-332.

Vrgovic, P., Vidicki, P., Glassman, B. and Walton, A. (2012), “Open innovation for SMEs in developing countries-An intermediated communication network model for collaboration beyond obstacles", Innovation, Vol. 14 No. 3, pp. 290-302.

Woy, U. and Qing, W. (2007), "Developing sustainable new product development procedures in SMEs utilising available tecnologies", International Journal of Agile Manufacturing, Vol. 10 No. 2, pp. 53-62.

Wu, Y.C., Lin, B.W. and Chen, C.J. (2013), "How do internal openness and external openness affect innovation capabilities and firm performance?", IEEE Transactions on Engineering Management, Vol. 60 No. 4, pp. 704-716.

Yu, D. and Shi, S. (2015), "Researching the development of Atanassov intuitionistic fuzzy set: Using a citation network analysis”, Applied Soft Computing, Vol. 32, pp. 189-198. 
Figure 1. Evolution of the number of publications on OI in SMEs.

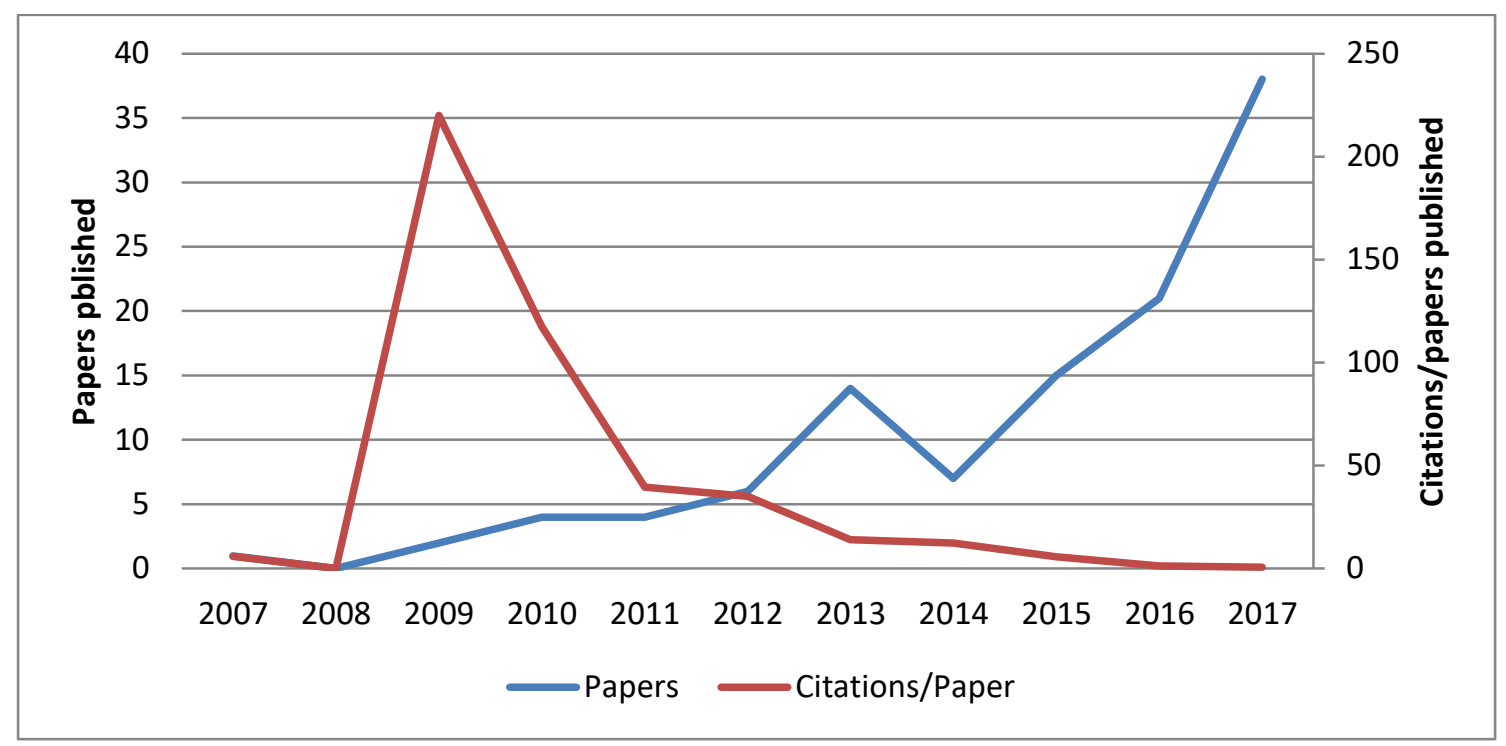

Figure 2. Co-citation analysis

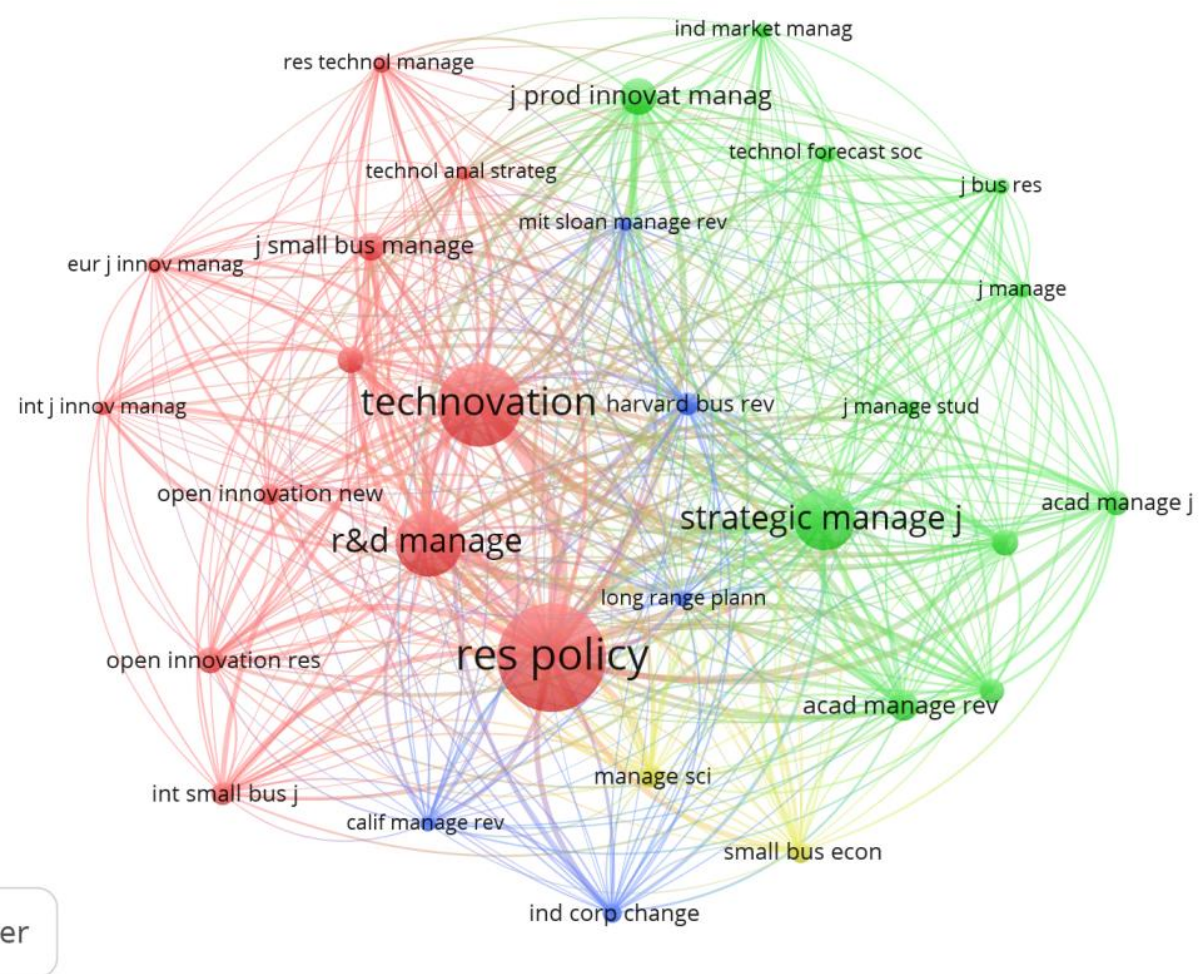

Note: The minimum number of citations from each source is 43 . 
Figure 3. Most influential authors (based on citations)

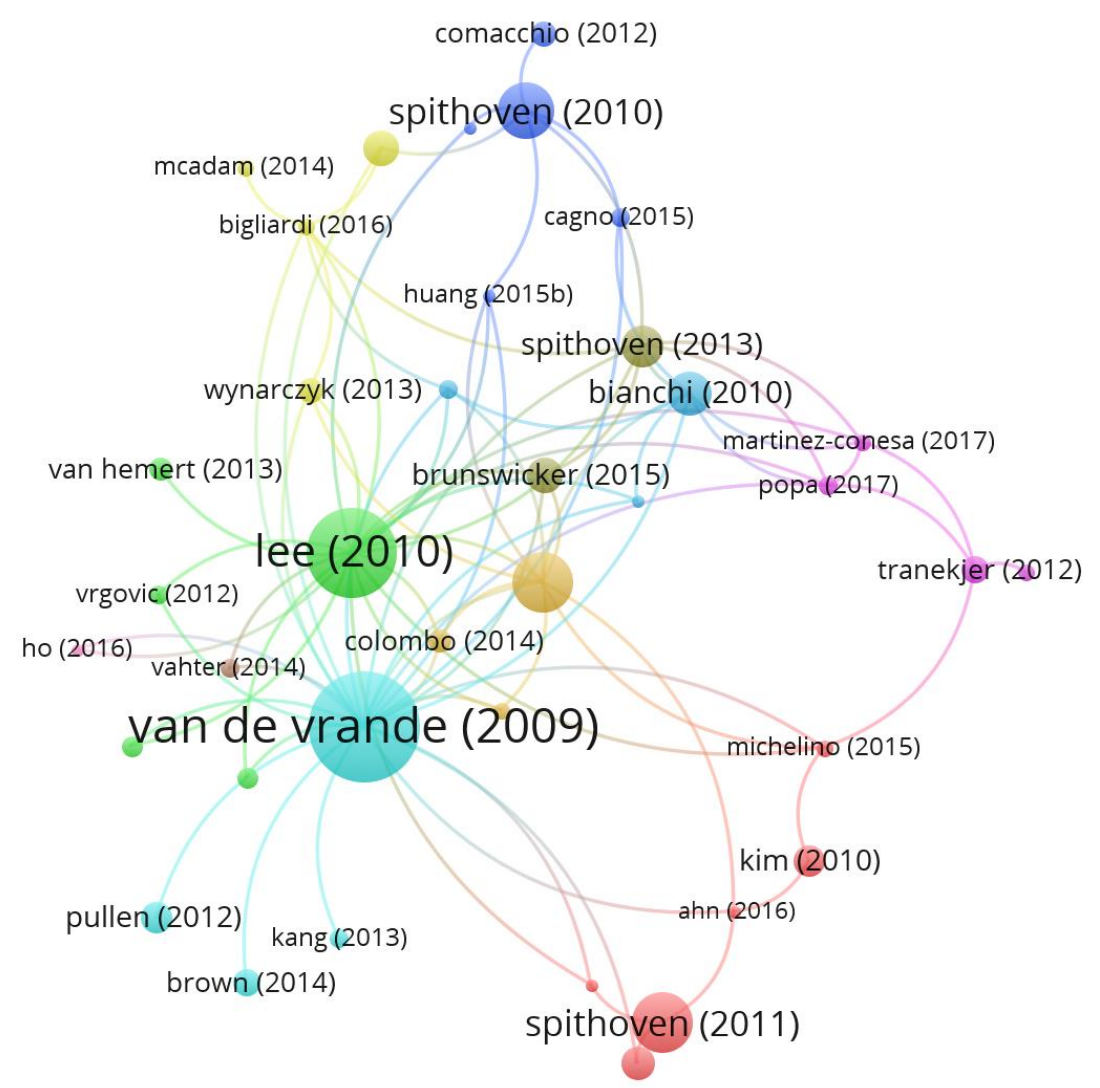

Figure 4. Bibliographic coupling by countries

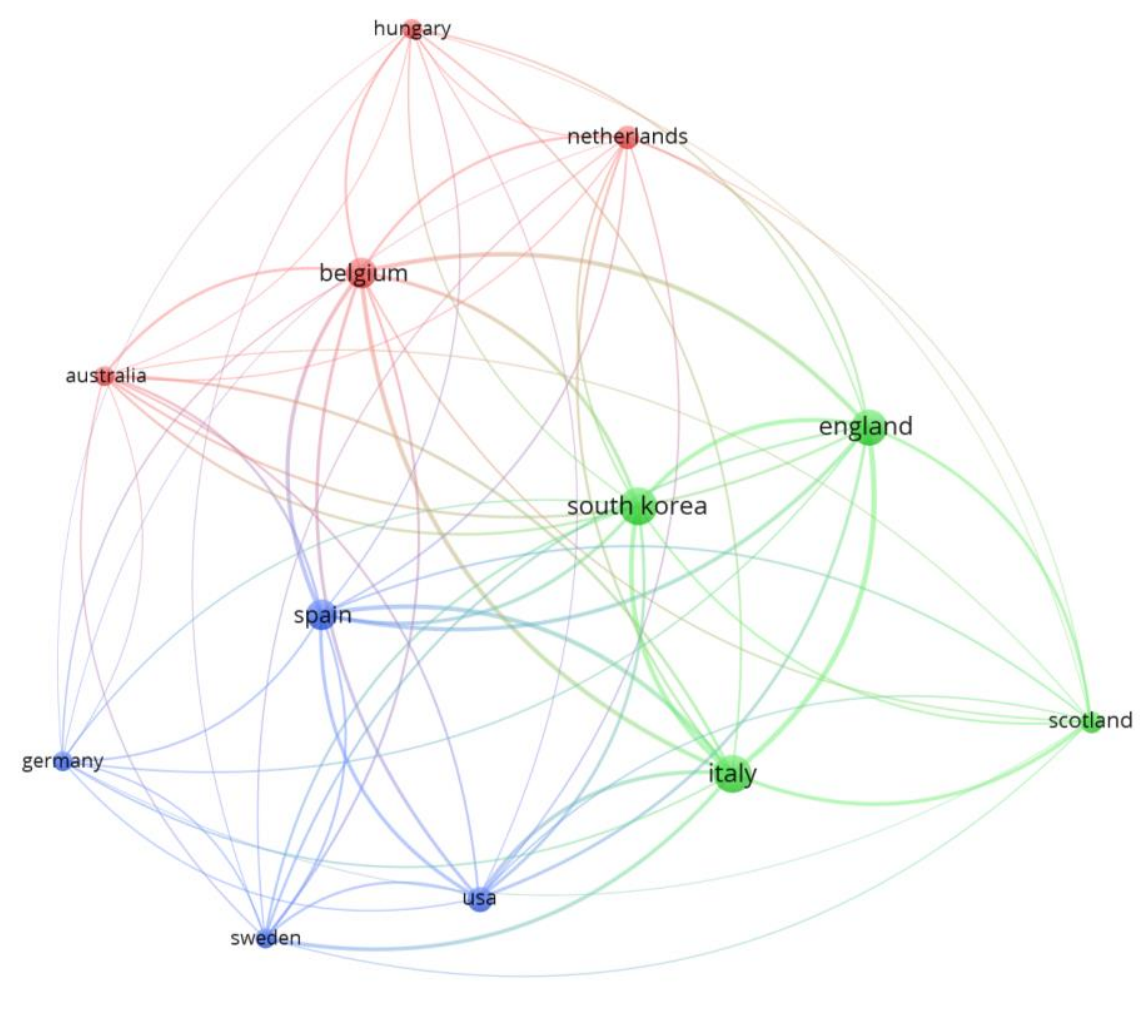


Figure 5. Top keywords employed in OI in SMEs articles

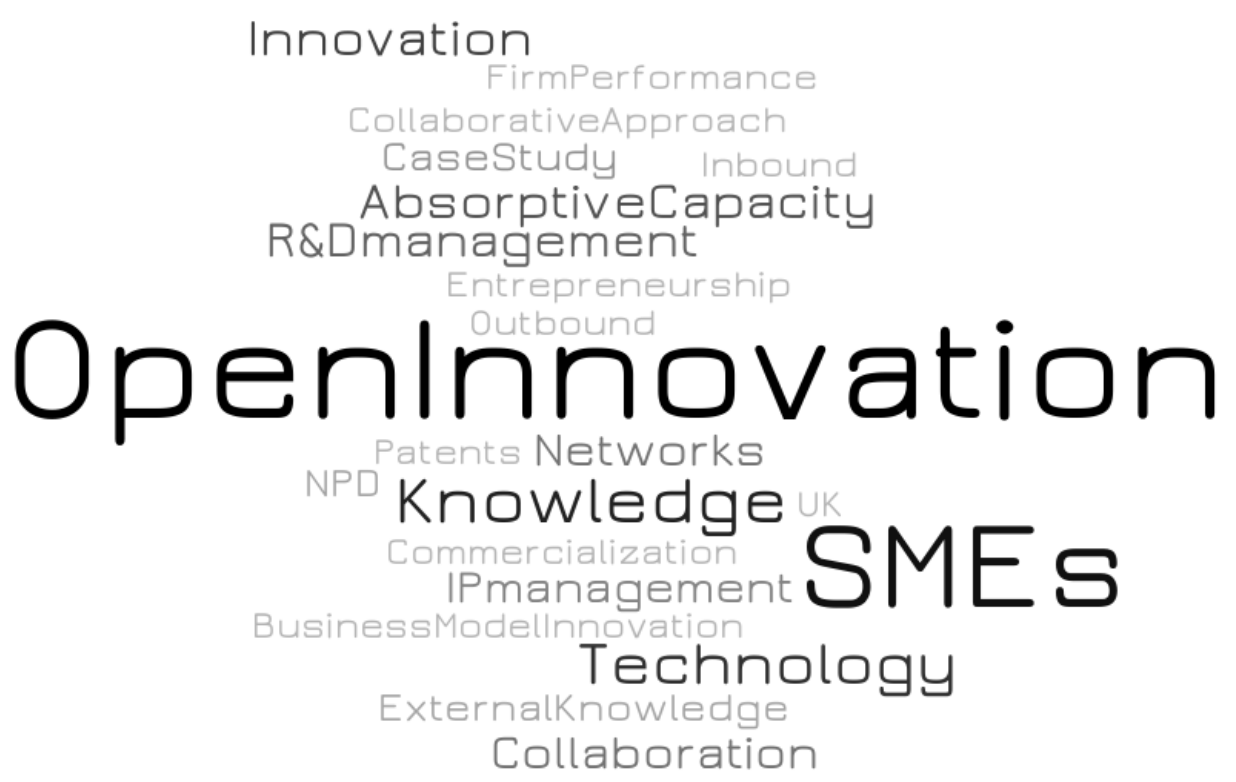

Figure 6. Co-citation analysis of keywords

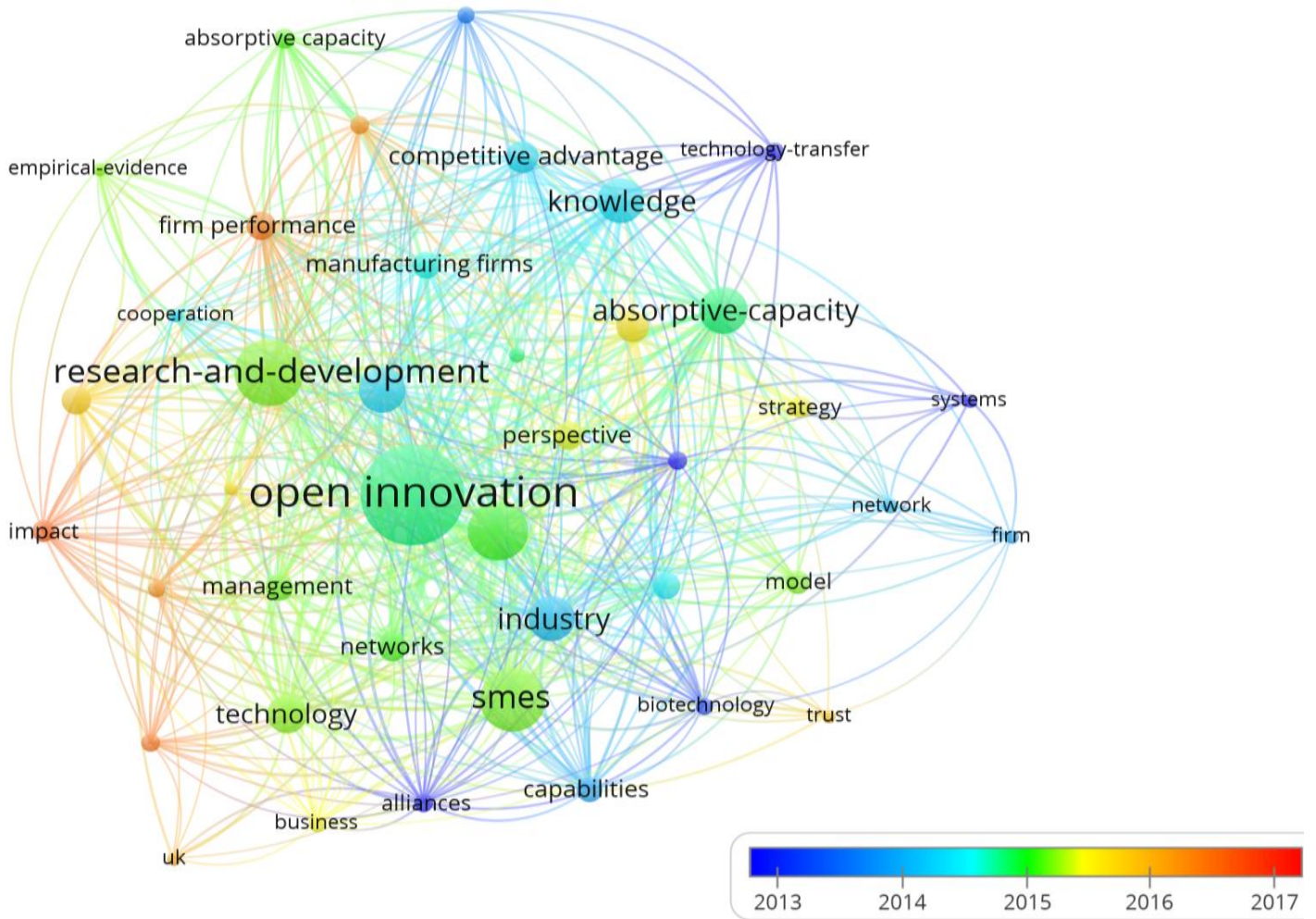


Figure 7. Map of most relevant terms

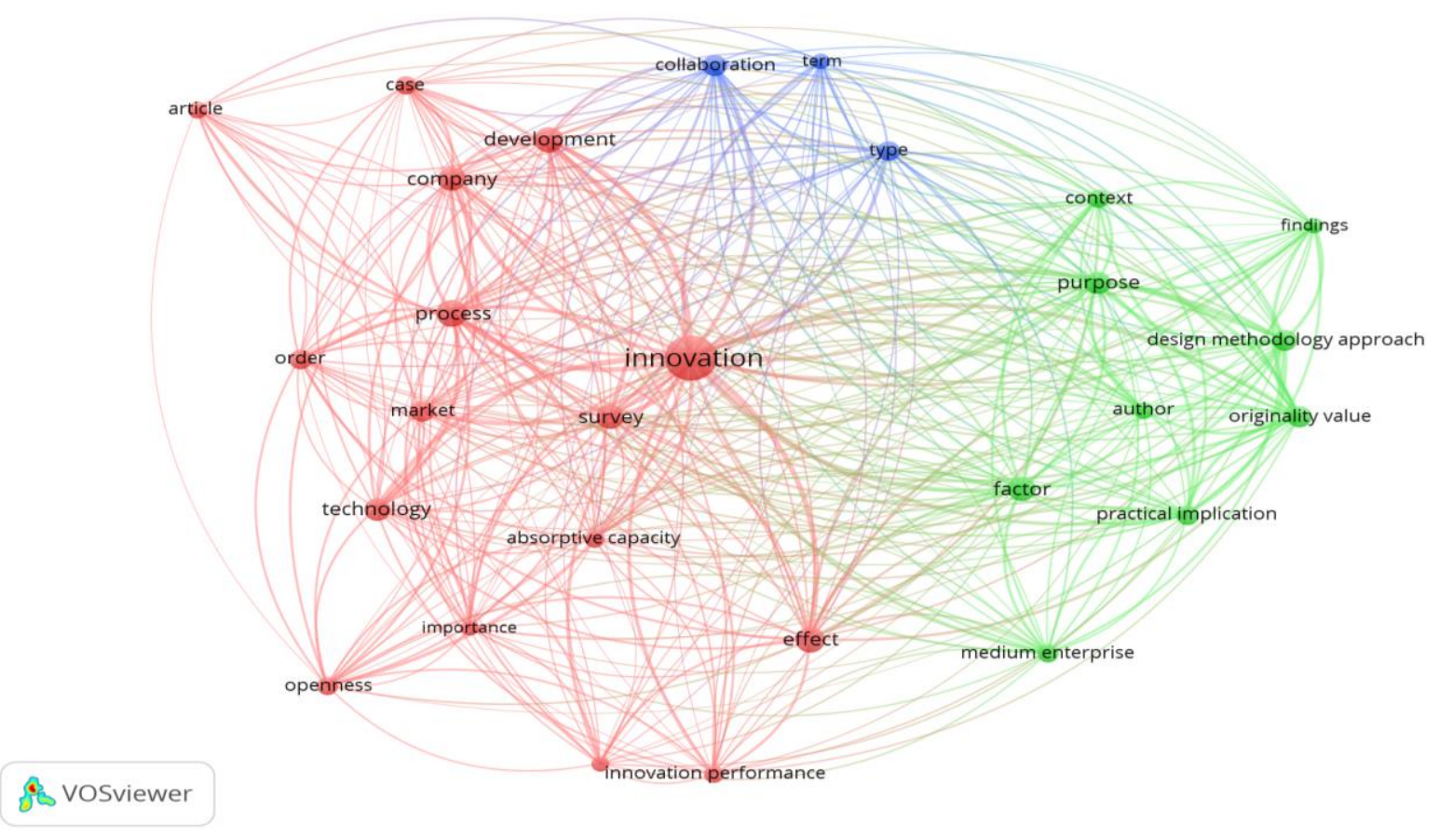


Table 1.50 most cited articles.

\begin{tabular}{|c|c|c|c|c|c|c|}
\hline $\mathbf{R}$ & Authors & Article title & Journal & TC & $\mathbf{Y}$ & TC/Y \\
\hline 1 & $\begin{array}{l}\text { van de Vrande, V; de Jong, JPJ; } \\
\text { Vanhaverbeke, W; de Rochemont, M }\end{array}$ & Open innovation in SMEs: Trends, motives and management challenges & Technovation & 433 & 2009 & 48.11 \\
\hline 2 & Lee, S; Park, G; Yoon, B; Park, J & Open innovation in SMEs-An intermediated network model & Res Policy & 280 & 2010 & 35.00 \\
\hline 3 & $\begin{array}{l}\text { Parida, V; Westerberg, M; } \\
\text { Frishammar, J }\end{array}$ & $\begin{array}{l}\text { Inbound Open Innovation Activities in High-Tech SMEs: The Impact on } \\
\text { Innovation Performance }\end{array}$ & J Small Bus Manage & 117 & 2012 & 19.50 \\
\hline 4 & $\begin{array}{l}\text { Spithoven, A; Clarysse, B; } \\
\text { Knockaert, M }\end{array}$ & $\begin{array}{l}\text { Building absorptive capacity to organise inbound open innovation in } \\
\text { traditional industries }\end{array}$ & Technovation & 114 & 2011 & 16.29 \\
\hline 5 & $\begin{array}{l}\text { Spithoven, A; Clarysse, B; } \\
\text { Knockaert, M }\end{array}$ & $\begin{array}{l}\text { Building absorptive capacity to organise inbound open innovation in } \\
\text { traditional industries }\end{array}$ & Technovation & 100 & 2010 & 12.50 \\
\hline 6 & $\begin{array}{l}\text { Bianchi, M; Campodall'Orto, S; } \\
\text { Frattini, F; Vercesi, P }\end{array}$ & $\begin{array}{l}\text { Enabling open innovation in small- and medium-sized enterprises: how to } \\
\text { find alternative applications for your technologies }\end{array}$ & R\&D Manage & 59 & 2010 & 7.38 \\
\hline 7 & $\begin{array}{l}\text { Spithoven, A; Vanhaverbeke, W; } \\
\text { Roijakkers, N }\end{array}$ & Open innovation practices in SMEs and large enterprises & Small Bus Econ & 56 & 2013 & 11.20 \\
\hline 8 & Brunswicker, S; Vanhaverbeke, W & $\begin{array}{l}\text { Open Innovation in Small and Medium-Sized Enterprises (SMEs): External } \\
\text { Knowledge Sourcing Strategies and Internal Organizational Facilitators }\end{array}$ & J Small Bus Manage & 37 & 2015 & 12.33 \\
\hline 9 & Teirlinck, P; Spithoven, A & $\begin{array}{l}\text { Research collaboration and R\&D outsourcing: Different R\&D personnel } \\
\text { requirements in SMEs }\end{array}$ & Technovation & 36 & 2013 & 7.20 \\
\hline 10 & Caetano, M; Amaral, DC & $\begin{array}{l}\text { Roadmapping for technology push and partnership: A contribution for open } \\
\text { innovation environments }\end{array}$ & Technovation & 34 & 2011 & 4.86 \\
\hline 11 & $\begin{array}{l}\text { Pullen, AJJ; de Weerd-Nederhof, PC; } \\
\text { Groen, AJ; Fisscher, OAM }\end{array}$ & $\begin{array}{l}\text { Open Innovation in Practice: Goal Complementarity and Closed NPD } \\
\text { Networks to Explain Differences in Innovation Performance for SMEs in } \\
\text { the Medical Devices Sector }\end{array}$ & J Prod Innovat Manag & 31 & 2012 & 5.17 \\
\hline 12 & Kim, H; Park, Y & $\begin{array}{l}\text { The effects of open innovation activity on performance of SMEs: the case } \\
\text { of Korea }\end{array}$ & Int J Technol Manage & 31 & 2010 & 3.88 \\
\hline 13 & Tranekjer, TL; Knudsen, MP & $\begin{array}{l}\text { The (Unknown) Providers to Other Firms' New Product Development: } \\
\text { What's in It for Them? }\end{array}$ & J Prod Innovat Manag & 22 & 2012 & 3.67 \\
\hline 14 & $\begin{array}{l}\text { Bocken, NMP; Farracho, M; } \\
\text { Bosworth, R; Kemp, R }\end{array}$ & $\begin{array}{l}\text { The front-end of eco-innovation for eco-innovative small and medium sized } \\
\text { companies }\end{array}$ & $\begin{array}{l}\text { J Eng Technol } \\
\text { Manage }\end{array}$ & 21 & 2014 & 5.25 \\
\hline 15 & Brown, R; Mason, C & $\begin{array}{l}\text { Inside the high-tech black box: A critique of technology entrepreneurship } \\
\text { policy }\end{array}$ & Technovation & 20 & 2014 & 5.00 \\
\hline 16 & $\begin{array}{l}\text { Wynarczyk, P; Piperopoulos, P; } \\
\text { McAdam, M }\end{array}$ & Open innovation in small and medium-sized enterprises: An overview & Int Small Bus J & 19 & 2013 & 3.80 \\
\hline 17 & Comacchio, A; Bonesso, S; Pizzi, C & $\begin{array}{l}\text { Boundary spanning between industry and university: the role of } \\
\text { Technology Transfer Centres }\end{array}$ & J Technol Transfer & 18 & 2012 & 3.00 \\
\hline
\end{tabular}




\begin{tabular}{|c|c|c|c|c|c|c|}
\hline 18 & $\begin{array}{l}\text { Colombo, MG; Piva, E; } \\
\text { Rossi-Lamastra, C }\end{array}$ & $\begin{array}{l}\text { Open innovation and within-industry diversification in small and medium } \\
\text { enterprises: The case of open source software firms }\end{array}$ & Res Policy & 16 & 2014 & 4.00 \\
\hline 19 & Andries, P; Faems, D & Patenting Activities and Firm Performance: Does Firm Size Matter? & J Prod Innovat Manag & 15 & 2013 & 3.00 \\
\hline 20 & $\begin{array}{l}\text { van Hemert, P; Nijkamp, P; } \\
\text { Masurel, E }\end{array}$ & $\begin{array}{l}\text { From innovation to commercialization through networks and } \\
\text { agglomerations: analysis of sources of innovation, innovation capabilities } \\
\text { and performance of Dutch SMEs }\end{array}$ & Ann Regional Sci & 14 & 2013 & 2.80 \\
\hline 21 & $\begin{array}{l}\text { Huang, HC; Lai, MC; Lin, LH; Chen, } \\
\text { CT }\end{array}$ & $\begin{array}{l}\text { Overcoming organizational inertia to strengthen business model innovation } \\
\text { An open innovation perspective }\end{array}$ & $\begin{array}{l}\text { J Organ Change } \\
\text { Manag }\end{array}$ & 13 & 2013 & 2.60 \\
\hline 22 & Suh, Y; Kim, MS & $\begin{array}{l}\text { Effects of SME collaboration on R\&D in the service sector in open } \\
\text { innovation }\end{array}$ & Innov-Manag Policy P & 13 & 2012 & 2.17 \\
\hline 23 & Verbano, C; Crema, M; Venturini, K & $\begin{array}{l}\text { The Identification and Characterization of Open Innovation Profiles in } \\
\text { Italian Small and Medium-sized Enterprises }\end{array}$ & J Small Bus Manage & 11 & 2015 & 3.67 \\
\hline 24 & $\begin{array}{l}\text { Popa, S; Soto-Acosta, P; } \\
\text { Martinez-Conesa, I }\end{array}$ & $\begin{array}{l}\text { Antecedents, moderators, and outcomes of innovation climate and open } \\
\text { innovation: An empirical study in SMEs }\end{array}$ & Technol Forecast Soc & 9 & 2017 & 9.00 \\
\hline 25 & $\begin{array}{l}\text { Cagno, E; Ramirez-Portilla, A; } \\
\text { Trianni, A }\end{array}$ & $\begin{array}{l}\text { Linking energy efficiency and innovation practices: Empirical evidence } \\
\text { from the foundry sector }\end{array}$ & Energ Policy & 9 & 2015 & 3.00 \\
\hline 26 & Vahter, P; Love, JH; Roper, S & Openness and Innovation Performance: Are Small Firms Different? & Ind Innov & 9 & 2014 & 2.25 \\
\hline 27 & Kang, J; Gwon, SH; Kim, S; Cho, K & $\begin{array}{l}\text { Determinants of successful technology commercialization: implication for } \\
\text { Korean Government-sponsored SMEs }\end{array}$ & Asian J Technol Inno & 9 & 2013 & 1.80 \\
\hline 28 & Eppinger, E; Vladova, G & $\begin{array}{l}\text { Intellectual property management practices at small and medium-sized } \\
\text { enterprises }\end{array}$ & Int J Technol Manage & 9 & 2013 & 1.80 \\
\hline 29 & $\begin{array}{l}\text { Vrgovic, P; Vidicki, P; Glassman, B; } \\
\text { Walton, A }\end{array}$ & $\begin{array}{l}\text { Open innovation for SMEs in developing countries - An intermediated } \\
\text { communication network model for collaboration beyond obstacles }\end{array}$ & Innov-Manag Policy P & 9 & 2012 & 1.50 \\
\hline 30 & $\begin{array}{l}\text { Martinez-Conesa, I; Soto-Acosta, P; } \\
\text { Carayannis, EG }\end{array}$ & $\begin{array}{l}\text { On the path towards open innovation: assessing the role of knowledge } \\
\text { management capability and environmental dynamism in SMEs }\end{array}$ & J Knowl Manag & 8 & 2017 & 8.00 \\
\hline 31 & Bigliardi, B; Galati, F & Which factors hinder the adoption of open innovation in SMEs? & Technol Anal Strateg & 8 & 2016 & 4.00 \\
\hline 32 & $\begin{array}{l}\text { Michelino, F; Lamberti, E; } \\
\text { Cammarano, A; Caputo, M }\end{array}$ & Open models for innovation: an accounting-based perspective & Int $\mathrm{J}$ Technol Manage & 8 & 2015 & 2.67 \\
\hline 33 & $\begin{array}{l}\text { McAdam, M; McAdam, R; } \\
\text { Dunn, A; McCall, C }\end{array}$ & $\begin{array}{l}\text { Development of small and medium-sized enterprise horizontal innovation } \\
\text { networks: UK agri-food sector study }\end{array}$ & Int Small Bus J & 8 & 2014 & 2.00 \\
\hline 34 & $\begin{array}{l}\text { Dries, L; Pascucci, S; } \\
\text { Torok, A; Toth, J }\end{array}$ & $\begin{array}{l}\text { Keeping Your Secrets Public? Open Versus Closed Innovation Processes in } \\
\text { the Hungarian Wine Sector }\end{array}$ & Int Food Agribus Man & 8 & 2014 & 2.00 \\
\hline 35 & Tranekjer, TL; Sondergaard, HA & $\begin{array}{l}\text { Sources of innovation, their combinations and strengths - benefits at the } \\
\text { NPD project level }\end{array}$ & Int J Technol Manage & 8 & 2013 & 1.60 \\
\hline 36 & Zhao, XY; Zheng, YN & $\begin{array}{l}\text { Development of Chinese science and technology intermediaries and their } \\
\text { integration into the open innovation paradigm }\end{array}$ & Technol Anal Strateg & 8 & 2011 & 1.14 \\
\hline
\end{tabular}




\begin{tabular}{|c|c|c|c|c|c|c|}
\hline 37 & $\begin{array}{l}\text { Padilla-Melendez, A; } \\
\text { Del Aguila-Obra, AR; Lockett, N }\end{array}$ & $\begin{array}{l}\text { Shifting sands: Regional perspectives on the role of social capital in } \\
\text { supporting open innovation through knowledge transfer and exchange with } \\
\text { small and medium-sized enterprises }\end{array}$ & Int Small Bus J & 7 & 2013 & 1.40 \\
\hline 38 & Lee, YG; Park, SH; Song, YI & $\begin{array}{l}\text { Which is Better for a Firm's Financial Performance: An Externally Oriented } \\
\text { or Inwardly Oriented Innovation Strategy? An Empirical Study on Korean } \\
\text { SMEs }\end{array}$ & Asian J Technol Inno & 7 & 2009 & 0.78 \\
\hline 39 & Vigier, $\mathrm{P}$ & $\begin{array}{l}\text { Towards a citizen-driven innovation system in Europe - A governance } \\
\text { approach for a European innovation agenda }\end{array}$ & Innovation-Abingdon & 6 & 2007 & 0.55 \\
\hline 40 & $\begin{array}{l}\text { Ho, YP; Ruan, Y; } \\
\text { Hang, CC; Wong, PK }\end{array}$ & $\begin{array}{l}\text { Technology upgrading of Small-and-Medium-sized Enterprises (SMEs) } \\
\text { through a manpower secondment strategy A mixed-methods study of } \\
\text { Singapore's T-Up program }\end{array}$ & Technovation & 5 & 2016 & 2.50 \\
\hline 41 & Huang, HC; Lai, MC; Huang, WW & $\begin{array}{l}\text { Resource complementarity, transformative capacity, and inbound open } \\
\text { innovation }\end{array}$ & J Bus Ind Mark & 5 & 2015 & 1.67 \\
\hline 42 & Dodourova, M; Bevis, K & $\begin{array}{l}\text { Networking innovation in the European car industry: Does the Open } \\
\text { Innovation model fit? }\end{array}$ & Transport Res A-Pol & 5 & 2014 & 1.25 \\
\hline 43 & $\begin{array}{l}\text { Ahn, JM; Ju, Y; Moon, TH; Minshall, } \\
\text { T; Probert, D; Sohn, SY; Mortara, L }\end{array}$ & $\begin{array}{l}\text { Beyond absorptive capacity in open innovation process: the relationships } \\
\text { between openness, capacities and firm performance }\end{array}$ & Technol Anal Strateg & 4 & 2016 & 2.00 \\
\hline 44 & Heger, T; Boman, M & Networked foresight-The case of EIT ICT Labs & Technol Forecast Soc & 4 & 2015 & 1.33 \\
\hline 45 & Huang, F; Rice, J; Martin, N & $\begin{array}{l}\text { Does open innovation apply to China? Exploring the contingent role of } \\
\text { external knowledge sources and internal absorptive capacity in Chinese } \\
\text { large firms and SMEs }\end{array}$ & J Manage Organ & 4 & 2015 & 1.33 \\
\hline 46 & Peng, XB; Song, W; Duan, YZ & $\begin{array}{l}\text { Framework of open innovation in SMEs in an emerging economy: firm } \\
\text { characteristics, network openness, and network information }\end{array}$ & Int $\mathbf{J}$ Technol Manage & 4 & 2013 & 0.80 \\
\hline 47 & $\begin{array}{l}\text { Ritala, P; Henttonen, K; Salojarvi, H; } \\
\text { Sainio, LM; Saarenketo, S }\end{array}$ & $\begin{array}{l}\text { Gone fishing for knowledge? The effect of strategic orientations on the } \\
\text { scope of open knowledge search }\end{array}$ & Balt J Manag & 4 & 2013 & 0.80 \\
\hline 48 & $\begin{array}{l}\text { Schuurman, D; De Marez, L; } \\
\text { Ballon, P }\end{array}$ & $\begin{array}{l}\text { The Impact of Living Lab Methodology on Open Innovation Contributions } \\
\text { and Outcomes }\end{array}$ & Technol Innov Manag & 3 & 2016 & 1.50 \\
\hline 49 & Torok, A; Toth, J & Open characters of innovation management in the Hungarian wine industry & Agr Econ-Czech & 3 & 2013 & 0.60 \\
\hline 50 & Rehm, SV; Goel, L; Junglas, I & Role of Information Systems in Empowering Innovation Networks & Mis Q Exec & 2 & 2015 & 0.67 \\
\hline
\end{tabular}

Abbreviations: R, rank; TC, citations; $\mathrm{Y}$, year; TC/Y, total citations per year.

Note: The ranking is developed according to the number of articles (with a minimum of 2). In the case of a tie, the ratio TC/Y is considered. 
Table 2. 30 most influential journals in OI in SMEs

\begin{tabular}{|c|c|c|c|c|c|c|c|c|c|c|c|c|c|c|}
\hline $\mathbf{R}$ & Journal & $\mathbf{T P}$ & TC & TC/TP & H-index & $>\mathbf{3 0 0}$ & $>200$ & $>100$ & $>\mathbf{5 0}$ & $>25$ & $>\mathbf{1 0}$ & FYW & IF & IF5 \\
\hline 1 & International Journal of Technology Management & 9 & 62 & 6.89 & 4 & 0 & 0 & 0 & 0 & 1 & 1 & 1997 & 1.036 & 1.106 \\
\hline 2 & Technovation & 7 & 742 & 106.00 & 6 & 1 & 2 & 2 & 2 & 3 & 4 & 1997 & 3.265 & 4.822 \\
\hline 3 & International Small Business Journal & 4 & 34 & 8.50 & 3 & 0 & 0 & 0 & 0 & 0 & 1 & 2005 & 3.677 & 4.651 \\
\hline 4 & Technology Analysis \& Strategic Management & 4 & 21 & 5.25 & 3 & 0 & 0 & 0 & 0 & 0 & 0 & 2005 & 1.273 & 1.686 \\
\hline 5 & Business Process Management Journal & 4 & 4 & 1.00 & 1 & 0 & 0 & 0 & 0 & 0 & 0 & NA & NA & NA \\
\hline 6 & Management Decision & 4 & 0 & 0.00 & 0 & 0 & 0 & 0 & 0 & 0 & 0 & 2009 & 1.396 & 2.515 \\
\hline 7 & Journal of Small Business Management & 3 & 165 & 55.00 & 3 & 0 & 0 & 1 & 1 & 2 & 3 & 1997 & 2.876 & 4.342 \\
\hline 8 & Journal of Product Innovation Management & 3 & 68 & 22.67 & 3 & 0 & 0 & 0 & 0 & 1 & 3 & 1997 & 3.759 & 4.358 \\
\hline 9 & R \& D Management & 3 & 60 & 20.00 & 1 & 0 & 0 & 0 & 1 & 1 & 1 & 1997 & 2.444 & 2.913 \\
\hline 10 & Technological Forecasting and Social Change & 3 & 14 & 4.67 & 2 & 0 & 0 & 0 & 0 & 0 & 0 & 1997 & 2.625 & 3.226 \\
\hline 11 & Technology Innovation Management Review & 3 & 4 & 1.33 & 1 & 0 & 0 & 0 & 0 & 0 & 0 & NA & NA & NA \\
\hline 12 & Sustainability & 3 & 1 & 0.33 & 1 & 0 & 0 & 0 & 0 & 0 & 0 & 2013 & 1.789 & 1.85 \\
\hline 13 & European Journal of Innovation Management & 3 & 0 & 0.00 & 0 & 0 & 0 & 0 & 0 & 0 & 0 & NA & NA & NA \\
\hline 14 & International Journal of Innovation Management & 3 & 0 & 0.00 & 0 & 0 & 0 & 0 & 0 & 0 & 0 & NA & NA & NA \\
\hline 15 & Research Policy & 2 & 296 & 148.00 & 2 & 0 & 1 & 1 & 1 & 1 & 2 & 1997 & 4.495 & 6.265 \\
\hline 16 & Innovation-Management Policy \& Practice & 2 & 22 & 11.00 & 2 & 0 & 0 & 0 & 0 & 0 & 1 & 2009 & 0.950 & 0.994 \\
\hline 17 & Asian Journal of Technology Innovation & 2 & 16 & 8.00 & 2 & 0 & 0 & 0 & 0 & 0 & 0 & 2010 & 0.698 & 0.855 \\
\hline 18 & Industry and Innovation & 2 & 10 & 5.00 & 1 & 0 & 0 & 0 & 0 & 0 & 0 & 2010 & 0.791 & 1.534 \\
\hline 19 & Journal of Knowledge Management & 2 & 8 & 4.00 & 1 & 0 & 0 & 0 & 0 & 0 & 0 & 2011 & 2.053 & 3.293 \\
\hline 20 & Agricultural Economics-Zemedelska Ekonomika & 2 & 3 & 1.50 & 1 & 0 & 0 & 0 & 0 & 0 & 0 & 2009 & 0.789 & 0.751 \\
\hline 21 & South African Journal of Industrial Engineering & 2 & 1 & 0.50 & 1 & 0 & 0 & 0 & 0 & 0 & 0 & 2009 & 0.576 & 0.496 \\
\hline 22 & Inzinerine Ekonomika-Engineering Economics & 2 & 0 & 0.00 & 0 & 0 & 0 & 0 & 0 & 0 & 0 & 2010 & 0.726 & 0.815 \\
\hline 23 & Small Business Economics & 1 & 56 & 56.00 & 1 & 0 & 0 & 0 & 1 & 1 & 1 & 1997 & 2.421 & 3.414 \\
\hline 24 & Journal of Engineering and Technology Management & 1 & 21 & 21.00 & 1 & 0 & 0 & 0 & 0 & 0 & 1 & 1998 & 2.419 & 2.985 \\
\hline 25 & Journal of Technology Transfer & 1 & 18 & 18.00 & 1 & 0 & 0 & 0 & 0 & 0 & 1 & 2009 & 2.631 & 2.777 \\
\hline 26 & Annals of Regional Science & 1 & 14 & 14.00 & 1 & 0 & 0 & 0 & 0 & 0 & 1 & 1997 & 0.694 & 1.037 \\
\hline
\end{tabular}




\begin{tabular}{|l|l|r|r|r|r|r|r|r|r|r|r|r|r|r|}
\hline 27 & Journal of Organizational Change Management & 1 & 13 & 13.00 & 1 & 0 & 0 & 0 & 0 & 0 & 1 & 1997 & 0.761 & 1.192 \\
\hline 28 & Energy Policy & 1 & 9 & 9.00 & 1 & 0 & 0 & 0 & 0 & 0 & 0 & 1997 & 4.140 & 4.599 \\
\hline 29 & International Food and Agribusiness Management Review & 1 & 8 & 8.00 & 1 & 0 & 0 & 0 & 0 & 0 & 0 & 2011 & 0.443 & 0.816 \\
\hline 30 & Innovation-The European Journal of Social Science Research & 1 & 6 & 6.00 & 1 & 0 & 0 & 0 & 0 & 0 & 0 & 2009 & 0.811 & 1.267 \\
\hline
\end{tabular}

Abbreviations: R, rank; TP and TC, total papers and citations dealing with OI in SMEs; TC/TP, total citations divided by total papers; H-index on OI in SMEs; >300, >200, $>100,>50,>25,>10$, number of papers with more than 500, 200, 100, 50, 25 and 10 citations; FYW, first year in WoS; IF, impact factor 2016; IF5, 5 year impact factor 2016; NA, journals that have recently been included in WoS and still do not have an impact factor.

Note: The ranking is developed according to the number of articles. In the case of a tie, the ratio TC/TP is considered. 
Table 3. Most productive and influential authors in OI in SMEs

\begin{tabular}{|c|c|c|c|c|c|c|}
\hline $\mathbf{R}$ & Author & University & Country & $\mathbf{T P}$ & TC & TC/TP \\
\hline 1 & Vanhaverbeke, W & Hasselt University & Belgium & 4 & 526 & 131.5 \\
\hline 2 & Spithoven, A & Belgian Science Policy Office & Belgium & 4 & 306 & 76.5 \\
\hline 3 & Yoon, B & Dongguk University & South Korea & 4 & 281 & 70.3 \\
\hline 4 & Toth, J & Corvinus University of Budapest & Hungary & 4 & 11 & 2.8 \\
\hline 5 & Del Giudice, $\mathrm{M}$ & Sapienza - Università di Roma & Italy & 3 & 1 & 0.3 \\
\hline 6 & Scuotto, V & University of the West of Scotland & UK & 3 & 1 & 0.3 \\
\hline 7 & Yun, JJ & $\begin{array}{l}\text { Daegu Gyeongbuk Institute of Science and } \\
\text { Technology }\end{array}$ & South Korea & 3 & 0 & 0.0 \\
\hline 8 & Lee, $\mathrm{S}$ & Ajou University & South Korea & 2 & 281 & 140.5 \\
\hline 9 & Clarysse, B & University of Ghent & Belgium & 2 & 214 & 107.0 \\
\hline 10 & Knockaert, M & University of Ghent & Belgium & 2 & 214 & 107.0 \\
\hline 11 & Teirlinck, $\mathrm{P}$ & Katholieke Universiteit Leuven & Belgium & 2 & 37 & 18.5 \\
\hline 12 & Tranekjer, TL & University of Southern Denmark & Denmark & 2 & 30 & 15.0 \\
\hline 13 & McAdam, M & Queen's University Belfast & $\begin{array}{l}\text { North } \\
\text { Ireland }\end{array}$ & 2 & 27 & 13.5 \\
\hline 14 & Brown, R & University of St Andrews & $\mathrm{UK}$ & 2 & 21 & 10.5 \\
\hline 15 & Huang, H-C & $\begin{array}{l}\text { National Kaohsiung University of Applied } \\
\text { Sciences }\end{array}$ & Taiwan & 2 & 18 & 9.0 \\
\hline 16 & Lai, M-C & Tzu Chi College of Technology & Taiwan & 2 & 18 & 9.0 \\
\hline 17 & Martinez-Conesa, I & Universidad de Murcia & Spain & 2 & 17 & 8.5 \\
\hline 18 & Soto-Acosta, $\mathrm{P}$ & Universidad de Murcia & Spain & 2 & 17 & 8.5 \\
\hline 19 & Cagno, E & Politecnico di Milano & Italy & 2 & 10 & 5.0 \\
\hline 20 & Ramirez-Portilla, A & KTH Royal Institute of Technology & Sweden & 2 & 10 & 5.0 \\
\hline 21 & Carayannis, EG & George Washington University & USA & 2 & 9 & 4.5 \\
\hline 22 & Vladova, G & University of Potsdam & Germany & 2 & 9 & 4.5 \\
\hline 23 & Ahn, JM & Sogang University & South Korea & 2 & 4 & 2.0 \\
\hline 24 & Minshall, $\mathrm{T}$ & Sogang University & South Korea & 2 & 4 & 2.0 \\
\hline 25 & Mortara, L & University of Cambridge & England & 2 & 4 & 2.0 \\
\hline 26 & Alfaro Tanco, JA & Universidad de Navarra & Spain & 2 & 2 & 1.0 \\
\hline 27 & Agostini, L & Università di Padova & Italy & 2 & 1 & 0.5 \\
\hline 28 & Krause, W & Stellenbosch University & South Africa & 2 & 1 & 0.5 \\
\hline 29 & Nosella, A & Università di Padova & Italy & 2 & 1 & 0.5 \\
\hline 30 & Schutte, CSL & Stellenbosch University & South Africa & 2 & 1 & 0.5 \\
\hline 31 & Bresciani, S & University of Turin & Italy & 2 & 0 & 0.0 \\
\hline 32 & Ferto, I & Hungarian Academy of Sciences & Hungary & 2 & 0 & 0.0 \\
\hline 33 & Henttonen, $\mathrm{K}$ & Lappeenranta University of Technology & Finland & 2 & 0 & 0.0 \\
\hline 34 & Lee, $\mathrm{K}$ & Dongguk University & South Korea & 2 & 0 & 0.0 \\
\hline 35 & Park, KB & Sangji University & South Korea & 2 & 0 & 0.0 \\
\hline 36 & Yang, J & $\begin{array}{l}\text { Daegu Gyeongbuk Institute of Science and } \\
\text { Technology }\end{array}$ & South Korea & 2 & 0 & 0.0 \\
\hline
\end{tabular}

Abbreviations: R, rank; TP and TC, total papers and citations dealing with $\mathrm{OI}$ in SMEs; TC/TP, total citations divided by total papers;

Note: The ranking is developed according to the number of articles (TP) (with a minimum of 2). In the case of a tie, the ratio TC/TP is considered. 
Table 4. 50 most influential institutions in OI in SMEs

\begin{tabular}{|c|c|c|c|c|c|c|c|c|c|c|}
\hline $\mathrm{R}$ & University & Country & $\mathrm{TP}$ & TC & Impact & Authors & Authors/TP & Impact/Authors & ARWU & QS \\
\hline 1 & Hasselt University & Belgium & 4 & 526 & 131.5 & 3 & 0.8 & 175.3 & & \\
\hline 2 & Dongguk University & South Korea & 4 & 281 & 70.3 & 4 & 1.0 & 70.3 & $501-600$ & $471-480$ \\
\hline 3 & Politecnico di Milano & Italy & 4 & 85 & 21.3 & 8 & 2.0 & 10.6 & $201-300$ & 170 \\
\hline 4 & Corvinus University of Budapest & Hungary & 4 & 11 & 2.8 & 2 & 0.5 & 5.5 & & $801-1000$ \\
\hline 5 & Sungkyunkwan University & South Korea & 4 & 10 & 2.5 & 5 & 1.3 & 2.0 & & 108 \\
\hline 6 & Seoul National University & South Korea & 3 & 293 & 97.7 & 4 & 1.3 & 73.3 & $101-150$ & 36 \\
\hline 7 & University of Ghent & Belgium & 3 & 117 & 39.0 & 4 & 1.3 & 29.3 & 69 & 125 \\
\hline 8 & University of Southern Denmark & Denmark & 3 & 8 & 2.7 & 4 & 1.3 & 2.0 & $301-400$ & 384 \\
\hline 9 & University of Potsdam & Germany & 3 & 4 & 1.3 & 4 & 1.3 & 1.0 & $401-500$ & $461-470$ \\
\hline 10 & University of Cambridge & UK & 3 & 4 & 1.3 & 5 & 1.7 & 0.8 & 3 & 5 \\
\hline 11 & University of the West of Scotland & UK & 3 & 1 & 0.3 & 1 & 0.3 & 1.0 & & \\
\hline 12 & Università di Padova & Italy & 3 & 1 & 0.3 & 5 & 1.7 & 0.2 & $151-200$ & 296 \\
\hline 13 & Sogang University & South Korea & 3 & 0 & 0.0 & 5 & 1.7 & 0.0 & & $441-450$ \\
\hline 14 & Daegu Gyeongbuk Institute of Science and Technology & South Korea & 3 & 0 & 0.0 & 4 & 1.3 & 0.0 & & \\
\hline 15 & Ajou University & South Korea & 2 & 281 & 140.5 & 1 & 0.5 & 281.0 & $701-800$ & $6511-700$ \\
\hline 16 & Vlerick Business School & Belgium & 2 & 214 & 107.0 & 1 & 0.5 & 214.0 & & \\
\hline 17 & Belgian Science Policy Office & Belgium & 2 & 92 & 46.0 & 1 & 0.5 & 92.0 & & \\
\hline 18 & Purdue University & USA & 2 & 46 & 23.0 & 2 & 1.0 & 23.0 & $301-400$ & 105 \\
\hline 19 & University of Twente & Netherlands & 2 & 32 & 16.0 & 5 & 2.5 & 6.4 & $301-400$ & 179 \\
\hline 20 & Queen's University Belfast & North Ireland & 2 & 27 & 13.5 & 2 & 1.0 & 13.5 & $301-400$ & 202 \\
\hline 21 & University of Wageningen & Netherlands & 2 & 24 & 12.0 & 3 & 1.5 & 8.0 & $101-150$ & 124 \\
\hline 22 & University of St Andrews & UK & 2 & 21 & 10.5 & 1 & 0.5 & 21.0 & $301-400$ & 92 \\
\hline 23 & National Kaohsiung University of Applied Sciences & Taiwan & 2 & 18 & 9.0 & 4 & 2.0 & 4.5 & & \\
\hline 24 & Universidad de Murcia & Spain & 2 & 17 & 8.5 & 2 & 1.0 & 8.5 & $701-800$ & $801-1000$ \\
\hline 25 & Katholieke Universiteit Leuven & Belgium & 2 & 16 & 8.0 & 2 & 1.0 & 8.0 & 90 & 71 \\
\hline 26 & George Washington University & USA & 2 & 9 & 4.5 & 1 & 0.5 & 9.0 & $301-400$ & 352 \\
\hline
\end{tabular}




\begin{tabular}{|c|c|c|c|c|c|c|c|c|c|c|}
\hline 27 & University of Novi Sad & Serbia & 2 & 9 & 4.5 & 4 & 2.0 & 2.3 & & \\
\hline 28 & University of Science and Technology & South Korea & 2 & 7 & 3.5 & 1 & 0.5 & 7.0 & & \\
\hline 29 & Korea Institute of Science and Technology & South Korea & 2 & 7 & 3.5 & 4 & 2.0 & 1.8 & $201-300$ & 41 \\
\hline 30 & University of Science and Technology & China & 2 & 4 & 2.0 & 3 & 1.5 & 1.3 & $501-600$ & 97 \\
\hline 31 & Lappeenranta University of Technology & Finland & 2 & 4 & 2.0 & 5 & 2.5 & 0.8 & & $501-550$ \\
\hline 32 & Universidad de Navarra & Spain & 2 & 2 & 1.0 & 2 & 1.0 & 1.0 & & 270 \\
\hline 33 & National Research University & Russia & 2 & 1 & 0.5 & 2 & 1.0 & 0.5 & & 382 \\
\hline 34 & Sapienza - Università di Roma & Italy & 2 & 1 & 0.5 & 2 & 1.0 & 0.5 & $151-200$ & 215 \\
\hline 35 & Stellenbosch University & South Africa & 2 & 1 & 0.5 & 2 & 1.0 & 0.5 & $401-500$ & 361 \\
\hline 36 & Hungarian Academy of Sciences & Hungary & 2 & 0 & 0.0 & 2 & 1.0 & 0.0 & & \\
\hline 37 & Sangji University & South Korea & 2 & 0 & 0.0 & 2 & 1.0 & 0.0 & & \\
\hline 38 & University of Turin & Italy & 2 & 0 & 0.0 & 2 & 1.0 & 0.0 & $201-300$ & $551-600$ \\
\hline 39 & École Polytechnique Fédérale de Lausanne & Switzerland & 1 & 433 & 433.0 & 1 & 1.0 & 433.0 & 76 & 12 \\
\hline 40 & Eindhoven University of Technology & Netherlands & 1 & 433 & 433.0 & 1 & 1.0 & 433.0 & $301-400$ & 104 \\
\hline 41 & Electronics and Telecommunications Research Institute & South Korea & 1 & 280 & 280.0 & 1 & 1.0 & 280.0 & & \\
\hline 42 & Luleå University of Technology & Sweden & 1 & 117 & 117.0 & 1 & 1.0 & 117.0 & & \\
\hline 43 & Sant'Anna School of Advanced Studies & Italy & 1 & 59 & 59.0 & 1 & 1.0 & 59.0 & & 192 \\
\hline 44 & University of Bergamo & Italy & 1 & 59 & 59.0 & 1 & 1.0 & 59.0 & & \\
\hline 45 & Budapest University of Technology and Economics & Hungary & 1 & 56 & 56.0 & 1 & 1.0 & 56.0 & $701-800$ & $751-800$ \\
\hline 46 & Hogeschool-Universiteit Brussel & Belgium & 1 & 36 & 36.0 & 1 & 1.0 & 36.0 & & \\
\hline 47 & Universidade de São Paulo & Brazil & 1 & 34 & 34.0 & 2 & 2.0 & 17.0 & $151-200$ & 121 \\
\hline 48 & University of Auckland & New Zealand & 1 & 21 & 21.0 & 1 & 1.0 & 21.0 & $201-300$ & 82 \\
\hline 49 & Maastricht University & Netherlands & 1 & 21 & 21.0 & 2 & 2.0 & 10.5 & $201-300$ & 200 \\
\hline 50 & University of Glasgow & UK & 1 & 20 & 20.0 & 1 & 1.0 & 20.0 & $101-150$ & 65 \\
\hline
\end{tabular}

Abbreviations: R, rank; TP and TC, total papers and citations dealing with OI in SMEs; Impact, TC/TP; Authors, number of authors belonging to this institution (in case of multiple affiliations, the country of the first one given in the paper is considered) that have published on this topic; ARWU, university position in the Academic Ranking of World Universities 2017; QS, university position in the QS World University Rankings ${ }^{\circledR} 2017$.

Note: The ranking is developed according to the number of articles (TP). In the case of a tie, the Impact is used. 
Table 5. Rank of countries publishing research on OI in SMEs

\begin{tabular}{|c|c|c|c|c|c|c|c|c|}
\hline $\mathrm{R}$ & Country & $\mathrm{TP}$ & $\mathrm{TC}$ & Impact & Authors & Impact/Authors & Institutions & Impact/Institutions \\
\hline 1 & UK & 19 & 90 & 25.83 & 25 & 1.23 & 17 & 2.35 \\
\hline 2 & Italy & 16 & 133 & 8.31 & 38 & 0.22 & 17 & 0.49 \\
\hline 3 & South Korea & 12 & 310 & 25.83 & 21 & 1.23 & 11 & 2.35 \\
\hline 4 & Belgium & 11 & 801 & 72.82 & 14 & 5.20 & 8 & 9.10 \\
\hline 5 & Netherlands & 8 & 539 & 67.38 & 15 & 4.49 & 6 & 11.23 \\
\hline 6 & Spain & 8 & 29 & 3.63 & 18 & 0.20 & 10 & 0.36 \\
\hline 7 & Hungary & 6 & 68 & 11.33 & 6 & 1.89 & 4 & 2.83 \\
\hline 8 & USA & 6 & 68 & 11.33 & 7 & 1.62 & 6 & 1.89 \\
\hline 9 & China & 6 & 19 & 3.17 & 19 & 0.17 & 7 & 0.45 \\
\hline 10 & Germany & 6 & 16 & 2.67 & 7 & 0.38 & 4 & 0.67 \\
\hline 11 & Sweden & 4 & 122 & 30.55 & 6 & 5.08 & 4 & 7.63 \\
\hline 12 & Finland & 4 & 5 & 1.25 & 11 & 0.11 & 4 & 0.31 \\
\hline 13 & Australia & 4 & 5 & 1.25 & 9 & 0.14 & 8 & 0.16 \\
\hline 14 & Denmark & 3 & 30 & 10.00 & 6 & 1.67 & 3 & 3.33 \\
\hline 15 & Taiwan & 3 & 18 & 6.00 & 9 & 0.67 & 5 & 1.20 \\
\hline 16 & Serbia & 3 & 9 & 3.00 & 9 & 0.33 & 3 & 1.00 \\
\hline 17 & North Ireland & 2 & 27 & 13.50 & 5 & 2.70 & 2 & 6.75 \\
\hline 18 & New Zealand & 2 & 21 & 10.50 & 2 & 5.25 & 2 & 5.25 \\
\hline 19 & U Arab Emirates & 2 & 2 & 1.00 & 2 & 0.50 & 2 & 0.50 \\
\hline 20 & Portugal & 2 & 2 & 1.00 & 6 & 0.17 & 3 & 0.33 \\
\hline 21 & Russia & 2 & 1 & 0.50 & 2 & 0.25 & 1 & 0.50 \\
\hline 22 & South Africa & 2 & 1 & 0.50 & 2 & 0.25 & 1 & 0.50 \\
\hline 23 & France & 2 & 0 & 0.00 & 5 & 0.00 & 4 & 0.00 \\
\hline 24 & Poland & 2 & 0 & 0.00 & 3 & 0.00 & 2 & 0.00 \\
\hline 25 & Switzerland & 1 & 433 & 433.00 & 1 & 433.00 & 1 & 433.00 \\
\hline 26 & Brazil & 1 & 34 & 34.00 & 2 & 17.00 & 1 & 34.00 \\
\hline 27 & Estonia & 1 & 9 & 9.00 & 1 & 9.00 & 1 & 9.00 \\
\hline 28 & Singapore & 1 & 5 & 5.00 & 3 & 1.67 & 1 & 5.00 \\
\hline 29 & Romania & 1 & 2 & 2.00 & 5 & 0.40 & 2 & 1.00 \\
\hline 30 & Canada & 1 & 1 & 1.00 & 1 & 1.00 & 1 & 1.00 \\
\hline 31 & Greece & 1 & 1 & 1.00 & 2 & 0.50 & 1 & 1.00 \\
\hline 32 & Mexico & 1 & 1 & 1.00 & 2 & 0.50 & 1 & 1.00 \\
\hline 33 & Lithuania & 1 & 0 & 0.00 & 3 & 0.00 & 1 & 0.00 \\
\hline 34 & Nigeria & 1 & 0 & 0.00 & 2 & 0.00 & 1 & 0.00 \\
\hline 35 & Slovenia & 1 & 0 & 0.00 & 4 & 0.00 & 1 & 0.00 \\
\hline
\end{tabular}

Abbreviations: R, rank; TP and TC, total papers and citations dealing with OI in SMEs; Impact, TC/TP; Authors, number of authors belonging to this country (in case of multiple affiliations, the country of the first one given in the paper is considered) that have published on this topic; Institutions, number of institutions in a given country (in case of multiple affiliations the first one is considered) in which authors that have published on this topic are affiliated at.

Note: The ranking is developed according to the number of articles (TP). In the case of a tie, the Impact is used. 